\title{
Total C-21 steroidal glycosides, isolated from the root tuber of Cynanchum auriculatum Royle ex Wight, attenuate hydrogen peroxide-induced oxidative injury and inflammation in LO2 cells
}

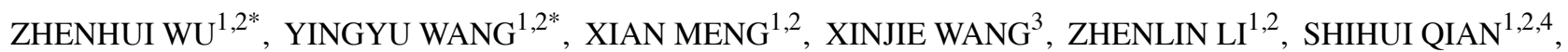 \\ YINGJIE WEI ${ }^{1,2}$, LUAN SHU ${ }^{1,2}$, YONGFANG DING ${ }^{1,2}$, PEIJUAN WANG $^{1,2}$ and YUNRU PENG ${ }^{1,2}$ \\ ${ }^{1}$ Department of Pharmacology, Affiliated Hospital of Integrated Traditional Chinese and Western Medicine, \\ Nanjing University of Chinese Medicine, Nanjing, Jiangsu 210023; ${ }^{2}$ Department of Pharmacology, \\ Jiangsu Province Academy of Chinese Medicine, Nanjing, Jiangsu 210028; ${ }^{3}$ State Key Laboratory of Natural \\ Medicines, Research Department of Pharmacognosy, China Pharmaceutical University, Nanjing, Jiangsu 211198; \\ ${ }^{4}$ Jiangsu Provincial Platform for Conservation and Utilization of Agricultural Germplasm, Nanjing, Jiangsu 210014, P.R. China
}

Received April 28, 2018; Accepted September 20, 2018

DOI: $10.3892 / \mathrm{ijmm} .2018 .3896$

\begin{abstract}
Oxidative stress plays an important role in the pathology of liver disorders. Total C-21 steroidal glycosides (TCSGs), isolated from the root tuber of Cynanchum auriculatum Royle ex Wight, have been reported to exert numerous effects, including liver protective and antioxidant effects. In order to investigate the potential mechanisms underlying the protective effects of TCSGs on liver function, the present study used the human normal liver cell line, L02, to evaluate the effects of TCSGs on hydrogen peroxide $\left(\mathrm{H}_{2} \mathrm{O}_{2}\right)$-induced oxidative injury and inflammatory responses. The L02 cells were pretreated with various concentrations of TCSGs, followed by exposure to $1.5 \mathrm{mM} \mathrm{H}_{2} \mathrm{O}_{2}$. Cell viability was determined by a 3-(4,5-dimethylthiazol-2-yl)-2,5-diphenyltetrazolium bromide (MTT) assay. The levels of alanine aminotransferase (ALT), aspartate aminotransferase (AST), lactate dehydrogenase (LDH) and nitric oxide (NO) were measured using colorimetric assays. The activities of superoxide dismutase (SOD), catalase (CAT), glutathione peroxidase (GSH-Px) and the production of malondialdehyde (MDA) were also determined. Intracellular reactive oxygen species (ROS) levels were detected using a fluorescent probe.
\end{abstract}

Correspondence to: Professor Yunru Peng or Professor Peijuan Wang, Department of Pharmacology, Jiangsu Province Academy of Chinese Medicine, 100 Shizi Street, Hongshan Road, Nanjing, Jiangsu 210028, P.R. China

E-mail: pengyunru@126.com

E-mail: wangpeijuan1961@126.com

${ }^{*}$ Contributed equally

Key words: total C-21 steroidal glycosides, hydrogen peroxide, antioxidant, anti-inflammatory, nuclear factor erythroid 2-related factor 2, nuclear factor- $\mathrm{kB}$
$\mathrm{H}_{2} \mathrm{O}_{2}$-induced oxidative toxicity was attenuated following treatment with TCSGs, as indicated by the increase in cell viability, the decreased levels of ALT, AST, LDH, NO, MDA and ROS, and the increased activities of SOD, CAT and GSH-Px. To further explore the possible mechanisms of action of TCSGs, the nuclear factor erythroid 2-related factor 2 (Nrf2) and nuclear factor- $\kappa \mathrm{B}(\mathrm{NF})-\kappa \mathrm{B}$ pathways were examined. The results revealed that treatment with TCSGs markedly induced Nrf2 nuclear translocation and upregulated the expression of heme oxygenase-1 (HO-1) in the L02 cells damaged by $\mathrm{H}_{2} \mathrm{O}_{2}$. In addition, pretreatment with TCSGs inhibited the NF- $\kappa \mathrm{B}$ signaling pathway by blocking the degradation of the inhibitor of nuclear factor $\kappa \mathrm{B} \alpha(\mathrm{I} \kappa \mathrm{B} \alpha)$, thereby reducing the expression and nuclear translocation of $\mathrm{NF}-\kappa \mathrm{B}$, as well as reducing the expression of tumor necrosis factor- $\alpha$ (TNF- $\alpha$ ), interleukin-6 (IL-6), inducible nitric oxide synthase (iNOS) and cyclooxygenase 2 (COX-2). On the whole, the findings of this study demonstrate that TCSGs can protect L02 cells against $\mathrm{H}_{2} \mathrm{O}_{2}$-induced oxidative toxicity and inflammatory injury by increasing the expression of Nrf2 and HO-1, mediated by the $\mathrm{NF}-\kappa \mathrm{B}$ signaling pathway.

\section{Introduction}

Cynanchum auriculatum (C. auriculatum) Royle ex Wight, a member of the Asclepiadaceae family, is widely distributed in China. The root tuber of $C$. auriculatum Royle ex Wight, a well-known traditional Chinese herbal medicine known as 'Baishouwu' has been used as a local tonic and medicine for $>1,000$ years since the Tang Dynasty in China (1). Modern phytochemical and pharmacological studies have demonstrated that C-21 steroidal glycosides are the major active components of Baishouwu (2,3). The total C-21 steroidal glycosides (TCSGs), isolated from Baishouwu, possess various pharmacological activities, including antitumor (4-11), aging-attenuating (12), free radical-scavenging (13), immunity-enhancing (14), depression-reducing (15) and fungus-suppressing (16) activities. Recently, it has been reported that the C-21 steroidal 
glycosides isolated from Baishouwu exhibit notable hepatoprotective effects in vivo (17). However, the underlying mechanisms remain largely unknown.

Pathological and experimental evidence has suggested that multiple mechanisms of hepatic injury are implicated in oxidative damage, inflammation, the dysfunction of intracellular targets and the innate immune system (18-20). It has been well established that cell oxidative stress damage induced by reactive oxygen species (ROS) is a principal mechanism of hepatic injury. When there is an imbalance in the levels of intracellular oxidative factors and antioxidants, oxidative stress can result in a disruption in redox signaling and cellular injury $(21,22)$. An increasing body of evidence has indicated that superoxide anion and hydrogen peroxide $\left(\mathrm{H}_{2} \mathrm{O}_{2}\right)$ are associated with various pathological diseases, such as viral hepatitis (23), alcoholic hepatitis (24) and non-alcoholic fatty liver diseases (NAFLD) (25). $\mathrm{H}_{2} \mathrm{O}_{2}$-induced hepatic injury is a common cell model for investigating the potential hepatoprotective activity (26). Lipid peroxidation is one of the significant causes of $\mathrm{H}_{2} \mathrm{O}_{2}$-induced hepatic injury and can be monitored by detecting the content of intracellular malondialdehyde (MDA). The disruption of the hepatic antioxidant defense system is characterized by increased MDA and/or altered enzymatic antioxidants, including superoxide dismutase (SOD), catalase (CAT) and glutathione peroxidase (GSH-Px). The superoxide radical $\left(\mathrm{O}_{2}^{-}\right)$is an oxygen free radical that damages the body, which is then converted to $\mathrm{O}_{2}$ and $\mathrm{H}_{2} \mathrm{O}_{2}$ by the action of SOD and detoxified to water by CAT or GSH-Px. The activities of these antioxidants have been used to evaluate oxidative stress levels in cells (27). Excessive ROS levels induced by $\mathrm{H}_{2} \mathrm{O}_{2}$ disrupt the balance between ROS production and the antioxidant defense system.

It has been reported that excessive ROS levels induced by $\mathrm{H}_{2} \mathrm{O}_{2}$ can induce nuclear factor (NF)- $\mathrm{kB}$ activation, and subsequently increase NF- $\kappa \mathrm{B}$ p65 subunit nuclear translocation (28). The activation of NF- $\mathrm{kB}$ is enhanced by increasing the degradation and phosphorylation of inhibitor of nuclear factor- $\kappa \mathrm{B}(\mathrm{I} \kappa \mathrm{B})$, which further modulates the hepatic injury by regulating proinflammatory cytokine production, such as tumor necrosis factor (TNF)- $\alpha$ and interleukin (IL)-6, and the expression of inflammatory mediators including inducible nitric oxide synthase (iNOS) and cyclooxygenase (COX)-2. Nitric oxide (NO) plays a critical role in hepatic injury caused by $\mathrm{H}_{2} \mathrm{O}_{2} \cdot \mathrm{H}_{2} \mathrm{O}_{2}$ exposure generates excessive levels of $\mathrm{NO}$ via the activation of iNOS, thereby leading to hepatic tissue damage (29).

In addition, a previous study revealed that the nuclear factor erythroid 2-related factor 2 (Nrf2) signaling pathway played an important role in the intracellular defense against oxidative stress (30). The nuclear transcription factor Nrf2 binds to antioxidant response elements (AREs) in order to activate antioxidant genes that are involved in the elimination of free radicals by promoting the expression of antioxidant enzymes, such as SOD and CAT (31). The role of the Nrf2/ARE signaling pathway in liver disease pathogenesis and its possible application as a underlying therapeutic target to block and treat chronic hepatitis, and alcoholic as well as non-alcoholic hepatic injury, have been extensively investigated (32).

The critical roles of oxidative stress and inflammation in the initiation and progression of liver injury have attracted increasing levels of attention (33). Previous studies have reported that $\mathrm{H}_{2} \mathrm{O}_{2}$-derived ROS production induced oxidative stress and promoted the generation of proinflammatory cytokines via the Nrf2 and NF-kB signaling pathway (34-37). Thus, redox-sensitive transcription factors, such as Nrf2 and $\mathrm{NF}-\mathrm{\kappa B}$, are essential transcription factors that modulate an array of antioxidant responses and proinflammatory gene expression in the liver (38).

Natural products derived from herbal medicines are attracting increasing attention as alternative treatment options for the prevention and treatment of liver diseases. TCSGs, the most important active components of Baishouwu, are commonly considered to be strong antioxidants due to their high free radical scavenging properties. Recent studies have revealed that TCSGs affect cellular inflammatory stress and inhibit tumors by regulating carcinogenesis-associated processes $(3,9,10,39)$. In addition, it has been demonstrated that TCSGs exert hepatoprotective effects against liver injury induced by carbon tetrachloride in vivo (17). To date, few studies have provided conclusive results, particularly with regard to the molecular mechanism of TCSGs in protecting hepatocytes against oxidative damage and inflammatory response.

The aim of the present study was to explore the possible protective effects of TCSGs on human liver cells against $\mathrm{H}_{2} \mathrm{O}_{2}$-induced oxidative damage by detecting oxidative stress indicators and inflammatory markers. More specifically, the potential molecular mechanisms of action of TCSGs were investigated by examining antioxidant and inflammatory signaling pathways. These results may elucidate the underlying protective mechanisms of TCSGs in liver injury.

\section{Materials and methods}

Plant material and preparation of TCSGs. The peeled root tubers of C. auriculatum were collected from Binhai County (Jiangsu, China) in December, 2015. The materials were identified and authenticated by Professor Shi-Hui Qian (Jiangsu Province Academy of Traditional Chinese Medicine, Jiangsu, China). A voucher specimen (no. WFC-20151225) was deposited at the Department of Natural Product Chemistry, Jiangsu Province Academy of Traditional Chinese Medicine (Nanjing, China). Chemical reference substances, namely caudatin-2,6-dideoxy-3-O-methy- $\beta$-D-cymaropyrano side (no. 1), wilfoside $\mathrm{C}_{1} \mathrm{~N}$ (no. 2), caudatin (no. 3), wilfoside $\mathrm{K}_{1} \mathrm{~N}$ (no. 4), wilfoside $\mathrm{C}_{1} \mathrm{G}$ (no. 5), cynauricuoside $A$ (no. 6), cynauricuoside C (no. 7) and auriculoside IV (no. 8) (Fig. 1), were isolated from $C$. auriculatum (40) and identified based on infrared, ultraviolet, mass spectrometry (MS) and nuclear magnetic resonance spectroscopic analyses (data not shown). The purity of these compounds was determined to be $>98 \%$ by high-performance liquid chromatography (HPLC) analysis. The root tubers were cut into small sectoins and boiled in 95\% ethanol (1:10) 2 times, $2 \mathrm{~h}$ each time, filtered through gauze and concentrated under reduced pressure to produce the ethanol extract. The ethanolic extract was extracted with ethyl acetate 3 times and then merged and evaporated to obtain the TCSG extract, as previously described (41). The main chemical components of the TCSGs were identified and determined by the ultra high-performance liquid chromatography triple quadrupole tandem mass spectrometry 
A

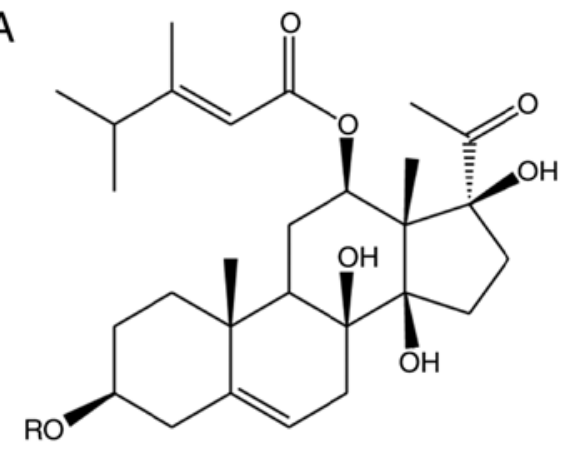<smiles>CC(=O)[C@]1(O)CC[C@]2(O)C3CC=C4C[C@@H](O)CC[C@]4(C)C3C[C@H](OC(=O)/C=C/c3ccccc3)[C@]12C</smiles>

$\begin{array}{ll}1 & \mathrm{R}=\mathrm{A} \\ 2 & \mathrm{R}=\mathrm{B} \\ 3 & \mathrm{R}=\mathrm{H} \\ 5 & \mathrm{R}=\mathrm{D} \\ 7 & \mathrm{R}=\mathrm{E}\end{array}$

$4 \quad \mathrm{R}=\mathrm{B}$

$6 \quad \mathrm{R}=\mathrm{D}$

$8 \quad \mathrm{R}=\mathrm{E}$

A:<smiles>CO[C@H]1C[C@@H](C)OC(C)C[C@H]1O</smiles>

B:

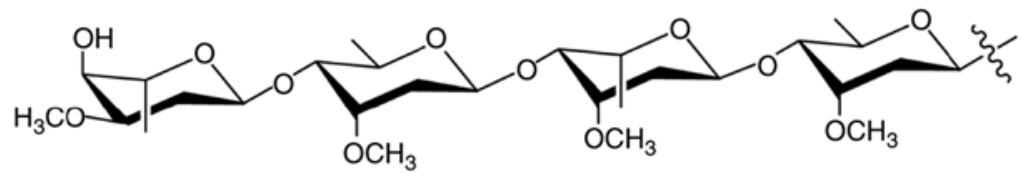

D:

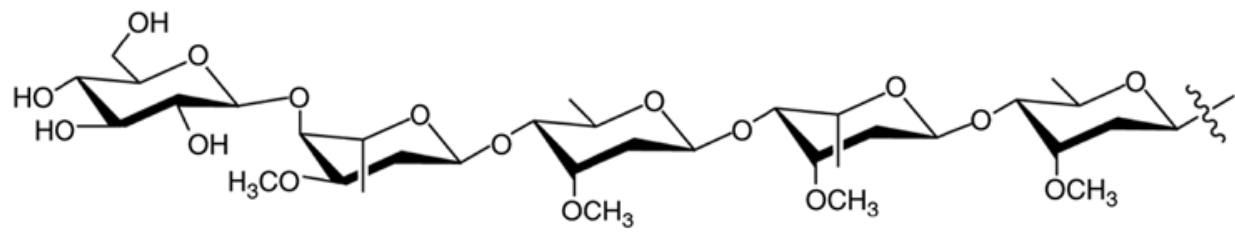

E:

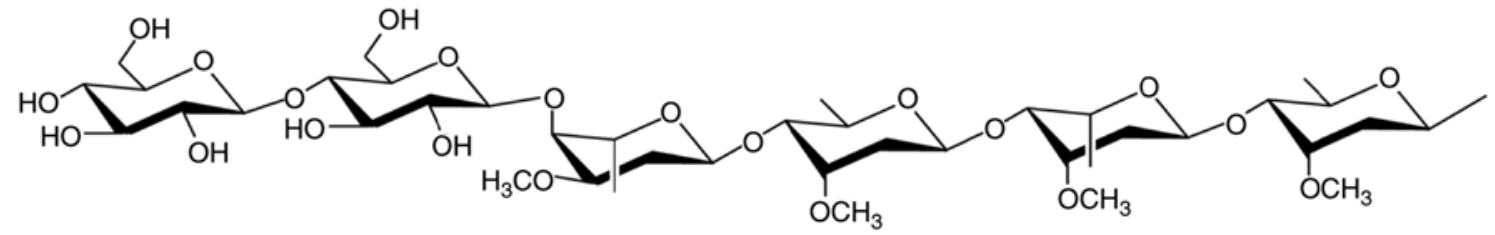

Figure 1. (A) Chemical structures of the 8 compounds.

method according to previously reported protocols (41). An Acquity UHPLC BEH $\mathrm{C}_{18}$ column $(2.1 \times 100 \mathrm{~mm}, 1.7 \mu \mathrm{m})$ was used for separations. The mobile phase was composed of (A) water $[0.1 \%(\mathrm{v} / \mathrm{v})$ formic acid] and (B) acetonitrile, and a linear gradient elution was used. MS was operated using an electrospray ionization (ESI) source in negative mode and the ESI-MS spectra were acquired by multiple reaction monitoring (MRM). Chlorzoxazone was used as the internal standard. A series of concentrations of standard solution were prepared for the establishment of the calibration curves. It was revealed that the TCSGs mainly contained $8 \mathrm{C}-21$ steroidal glycoside components, including caudatin-2,6-dideoxy-3-Omethy- $\beta$-D-cymaropyranoside $(20.11 \mathrm{mg} / \mathrm{g})$, wilfoside $\mathrm{C}_{1} \mathrm{~N}$ $(5.13 \mathrm{mg} / \mathrm{g})$, caudatin $(3.96 \mathrm{mg} / \mathrm{g})$, wilfoside $\mathrm{K}_{1} \mathrm{~N}(7.90 \mathrm{mg} / \mathrm{g})$, wilfoside $\mathrm{C}_{1} \mathrm{G}(73.25 \mathrm{mg} / \mathrm{g})$, cynauricuoside $\mathrm{A}(80.16 \mathrm{mg} / \mathrm{g})$, cynauricuoside C $(7.20 \mathrm{mg} / \mathrm{g})$ and auriculoside IV $(3.07 \mathrm{mg} / \mathrm{g})$. The chemical structures and the total ion chromatograms of the 8 compounds are presented in Fig. 1. The total glycosides content of the TCSGs was $73.5 \%$, as detected according to the vanillin-vitriol colorimetric method (42). The standard curve was constructed using the cynauricuoside A standard.

Reagents. $\mathrm{H}_{2} \mathrm{O}_{2}$ was purchased from Nanchang Baiyun Pharmaceutical Co., Ltd. (Nanchang, China). Fetal bovine serum (FBS) was purchased from Gibco/Thermo Fisher Scientific, Inc. (Waltham, MA, USA). Alanine aminotransferase (ALT; cat. no. C009-2), aspartate aminotransferase (AST; cat. no. C010-2), lactate dehydrogenase (LDH; cat. 

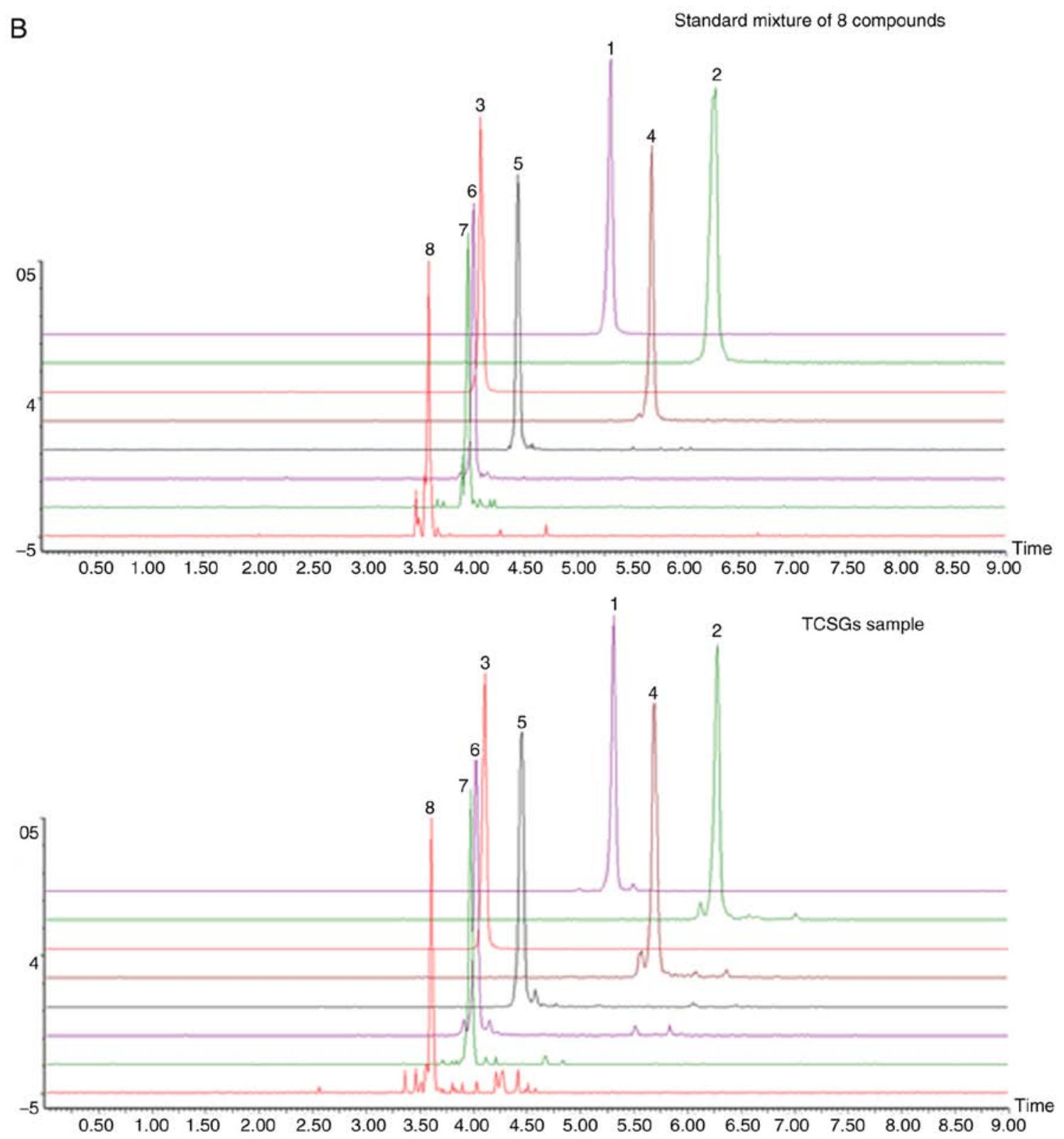

Figure 1. Continued. (B) The total ion chromatograms of 8 standard compounds and TCSGs by multiple reaction monitoring. No. 1, caudatin-2,6-dideoxy-3O-methy- $\beta$-D-cymaropyranoside; no. 2, wilfoside C1N; no. 3, caudatin; no. 4, wilfoside K1N; no. 5, wilfoside C1G; no. 6, cynauricuoside A; no. 7, cynauricuoside C; no. 8, auriculoside IV. TCSGs, total C-21 steroidal glycosides.

no. C020-2) and NO (cat. no. C013-2) assay kits were obtained from Nanjing Jiancheng Bioengineering Institute (Nanjing, China). SOD (cat. no. S0101), CAT (cat. no. S0051), GSH-Px (cat. no. S0058), MDA (cat. no. S0131) and ROS (cat. no. S0033) assay kits were purchased from Beyotime Institute of Biotechnology (Shanghai, China). Dulbecco's modified Eagle's medium (DMEM), the BCA protein quantification kit and the cytoplasmic-nuclear protein extraction kit were obtained from KeyGEN Biotech Co., Ltd. (Nanjing, China). Anti-iNOS (cat. no. 13120), anti-NF- $\kappa$ B (cat. no. 8242), anti-phospho-NF-kB p65 (cat. no. 3033) and anti-GAPDH (cat. no. 5174) antibodies were purchased from Cell Signaling Technology, Inc. (Danvers, MA, USA). Anti-IкB $\alpha$ (cat. no. abp57568) antibody was obtained from AmyJet Scientific (Wuhan, China). Anti-phospho-IкB $\alpha$ (cat. no. orb13487) antibody was obtained from Biorbyt (Wuhan, China). Anti-COX-2 (cat. no. ab15191) and anti-Lamin B1 (cat. no. ab133741) antibodies were purchased from Abcam (Cambridge, UK). Anti-heme oxygenase-1 (HO-1; cat. no. Pb0212) antibody was purchased from Wuhan Boster Biological Technology, Ltd. (Wuhan, China). Anti-Nrf2 (cat. no. Abs120634) antibody was obtained from Absin (Shanghai, China). Goat anti-rabbit (cat. no. AP307P) and mouse IgG (cat. no. AP124P) antibodies were purchased from EMD Millipore (Billerica, MA, USA).

Cell culture. L02 cells, a normal human hepatic cell line, were obtained from KeyGEN Biotech Co., Ltd. (cat. no. KG063) and used in the subsequent experiments, as previously described (43). The L02 cells were incubated at $37^{\circ} \mathrm{C}$ and $5 \% \mathrm{CO}_{2}$ in DMEM supplemented with $10 \% \mathrm{FBS}$ and $100 \mathrm{U} / \mathrm{ml}$ penicillin-streptomycin. Once cell confluence reached $\sim 80 \%$, the cells were passaged. 
Cell viability assay. The viability of the L02 cells was determined using the 3-(4,5-dimethyl-2-thiazolyl)-2,5-diphenyl-2-H-tetrazolium bromide (MTT) method. Firstly, the effective concentrations and treatment durations for TCSGs and $\mathrm{H}_{2} \mathrm{O}_{2}$ were determined using the cell viability data. The L02 cells at the exponential growth phase were suspended in DMEM $\left(5 \times 10^{3}\right.$ cells/well in $\left.100 \mu \mathrm{l}\right)$ and seeded into Corning disposable 96-well plates. Cell treatments were performed as follows: i) The cells were incubated with the TCSGs $(0,5,10$, $15,20,25,30,35,40$ and $45 \mu \mathrm{g} / \mathrm{ml}$ ) for 24,48 and $72 \mathrm{~h}$; ii) The cells were cultured for $72 \mathrm{~h}$ and then treated with $\mathrm{H}_{2} \mathrm{O}_{2}(0,0.2$, $0.4,0.6,0.8,1.0,1.2,1.5$ and $2 \mathrm{mM}$ ) for $24 \mathrm{~h}$. The cells were then washed with PBS, and $10 \mu \mathrm{l}$ of MTT solution $(5 \mathrm{mg} / \mathrm{ml})$ were added to each well and the plate was incubated for $4 \mathrm{~h}$. Then cell supernatants were discarded and $150 \mu$ l dimethyl sulfoxide were added to each well. The formazan crystals in the wells were dissolved and the absorbance was read at $570 \mathrm{~nm}$ using the Universal Microplate Reader (Thermo Fisher Scientific, Inc.). During these experiments, the TCSG group $(0 \mu \mathrm{g} / \mathrm{ml})$ or the $\mathrm{H}_{2} \mathrm{O}_{2}$ group $(0 \mathrm{mM})$ was considered to be the control group (negative control) in each test, respectively. Based on the results obtained from the above-mentioned experiments, the effect of TCSGs on the viability of the L02 cells damaged by $\mathrm{H}_{2} \mathrm{O}_{2}$ was investigated as the selected protocol. There were 5 groups during this test: The control group (negative control), the $\mathrm{H}_{2} \mathrm{O}_{2}$ group (positive control), and the TCSGs I $(10 \mu \mathrm{g} / \mathrm{ml})$, TCSGs II $(20 \mu \mathrm{g} / \mathrm{ml})$ and TCSGs III $(40 \mu \mathrm{g} / \mathrm{ml})$ groups. Following exposure to the TCSGs $(0,10,20$ and $40 \mu \mathrm{g} / \mathrm{ml})$ for $48 \mathrm{~h}$, the cells were treated with or without $\mathrm{H}_{2} \mathrm{O}_{2}(1.5 \mathrm{mM})$ for $24 \mathrm{~h}$. MTT assay was then performed as described above.

Cell morphological changes assessment. Briefly, the L02 cells $\left(2 \times 10^{5}\right.$ cells/well) were incubated in corning disposable 6 -well plates at $37^{\circ} \mathrm{C}$ and $5 \% \mathrm{CO}_{2}$ for $24 \mathrm{~h}$. The cells were pretreated with the TCSGs $(0,10,20$ and $40 \mu \mathrm{g} / \mathrm{ml})$ for $48 \mathrm{~h}$, and then stimulated with or without $\mathrm{H}_{2} \mathrm{O}_{2}(1.5 \mathrm{mM})$ for $24 \mathrm{~h}$. Cell morphological changes were imaged under a contrast microscope (Zeiss, Axiovert 200; Zeiss GmbH, Jena, Germany).

Assay of AST, ALT and LDH activities and NO levels. The levels of NO and the activities of hepatocellular leakage enzymes were assayed using commercial assay kits according to the manufacturer's instructions, respectively. Exponential growth phase cells were cultured in corning disposable 96-well plates $\left(5 \times 10^{3}\right.$ cells/well in $\left.100 \mu \mathrm{l}\right)$ for $24 \mathrm{~h}$ and pretreated with the TCSGs $(0,10,20$ and $40 \mu \mathrm{g} / \mathrm{ml})$ for $48 \mathrm{~h}$, followed by exposure to, or the absence of, $1.5 \mathrm{mM} \mathrm{H}_{2} \mathrm{O}_{2}$ for $24 \mathrm{~h}$. The cell culture media were then collected for the detection of AST, ALT and LDH activities, and NO levels. The data were expressed as units per liter (U/l) and $\mu \mathrm{mol} / 1$, respectively.

Determination of SOD, CAT and GSH-Px activities, and MDA levels. Following treatment with TCSGs and/or $\mathrm{H}_{2} \mathrm{O}_{2}$ as described above, the cells were washed and lysed with radioimmunoprecipitation assay (RIPA) buffer containing $1 \mathrm{mM}$ phenylmethylsulfonyl fluoride (PMSF) and maintained on ice for $30 \mathrm{~min}$. Cell lysates were collected and centrifuged at $10,000 \mathrm{x} \mathrm{g}$ for $5 \mathrm{~min}$. The supernatants were used to detect the activities of SOD, CAT and GSH-Px, and the levels of MDA following the manufacturer's instructions. The protein contents of the supernatants were assayed using a BCA protein quantification kit.

Detection of ROS levels. To evaluate the direct effects of TCSGs on $\mathrm{H}_{2} \mathrm{O}_{2}$-induced oxidative stress in L02 cells, the intracellular ROS levels were observed and analyzed via a fluorescence microplate assay and fluorescence microscopy. According to the manufacturer's instructions and as previously described (44), the intracellular ROS levels were measured using the ROS assay kit. Briefly, exponential growth phase L02 cells were pretreated with or without TCSGs for $48 \mathrm{~h}$, followed by exposure to, or the absence of, $1.5 \mathrm{mM} \mathrm{H}_{2} \mathrm{O}_{2}$ for $24 \mathrm{~h}$. Following 3 washes with PBS, the L02 cells were treated with $10 \mu \mathrm{M}$ of the fluorescent probe, 2',7'-dichlorodihydrofluorescein diacetate (DCFH-DA; 1:1,000), and incubated for $20 \mathrm{~min}$ at $37^{\circ} \mathrm{C}$ in the dark. Finally, the cells preloaded with DCFH-DA were imaged with a fluorescence microscope (Olympus Corporation, Tokyo, Japan), and the DCF fluorescence intensity was detected with an EnSpire Multifunctional Microplate Reader (PerkinElmer Inc., Waltham, MA, USA) under a $488 \mathrm{~nm}$ excitation wavelength and $525 \mathrm{~nm}$ emission wavelength.

RNA extraction and reverse transcription-quantitative polymerase chain reaction $(R T-q P C R)$ detection. Total RNA was extracted from the L02 cells using TRIzol reagent (Invitrogen/Thermo Fisher Scientific, Inc.) and first-stand cDNA was obtained using the Thermo Fisher K1622 first-stand cDNA Synthesis kit (Thermo Fisher Scientific, Inc.). Gene-specific primer sequences were designed and synthesized by GenScript Inc., Nanjing, China, as previously described (45). The primer sequences utilized are presented in Table I.

The qPCR reactions were carried out in $20 \mu \mathrm{l}$ reaction mixtures containing $10 \mu \mathrm{l} 2 \mathrm{X}$ Real Time PCR Master Mix (SYBR-Green), $2 \mu \mathrm{l}$ primer mix (including forward and reverse primers), and $1 \mu \mathrm{l}$ cDNA diluted in RNase-free water. The housekeeping gene, GAPDH, was used as an internal standard. The levels of relative mRNA were analyzed using the $2^{-\Delta \Delta \mathrm{Cq}}$ comparative approach (46).

Western blot analysis. The L02 cells were lysed in RIPA buffer (containing $1 \mathrm{mM}$ PMSF) on ice for $30 \mathrm{~min}$ and total proteins were collected. The cytoplasmic and nuclear protein samples were extracted using the cytoplasmic-nuclear protein extraction kits. The protein concentration was detected using the BCA protein quantification kit. Equal amounts of proteins (50 $\mu \mathrm{g} /$ lane) were separated on 10\% SDS-PAGE and electroblotted onto polyvinylidene difluoride membranes (EMD Millipore). Following blocking with 5\% skim milk for $1 \mathrm{~h}$, the membranes were incubated overnight with primary antibodies (anti-iNOS, 1:1,000; anti-COX-2, 1:800; anti-NF-кB p65,

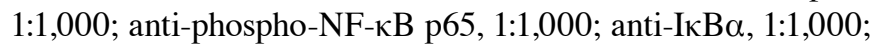
anti-phospho-IкB $\alpha, 1: 1,000$; anti-Nrf2, 1:500; anti-HO-1, 1:800; anti-Lamin B1, 1:1,000; and anti-GAPDH, 1:1,000) at $4^{\circ} \mathrm{C}$. Following 3 washes, the membranes were incubated for $1 \mathrm{~h}$ with goat anti-rabbit $\operatorname{IgG}(1: 2,000)$ and goat anti-mouse $\operatorname{IgG}$ $(1: 2,000)$ peroxidase-conjugated secondary antibodies at room temperature. The transferred proteins were visualized using an enhanced chemiluminescence detection kit (Beyotime Institute of Biotechnology, Shanghai, China) and the grayscale values 
Table I. Primer sequences used for reverse transcription-quantitative polymerase chain reaction.

\begin{tabular}{llr}
\hline Gene & \multicolumn{1}{c}{ Sequence (5'-3') } & Accession number \\
\hline TNF- $\alpha$ & F: GTCAACCTCCTCTCTGCCATCAAG & NM_000594 \\
TNF- $\alpha$ & R: CTGAGTCGGTCACCCTTCTCCA & \\
IL-6 & F: CTCAATATTAGAGTCTCAACCCCCA & NM_000600 \\
IL-6 & R: GAAGGCGCTTGTGGAGAAGG & \\
iNOS & F: GGAGCCAGCTCTGCATTATC & NM_000620 \\
iNOS & R: TTTTGTCTCCAAGGGACCAG & \\
COX-2 & F: TGCACTACATACTTACCCACTTCAA & NM_000963 \\
COX-2 & R: CAAATGTGATCTGGATGTCAACACA & \\
GAPDH & F: GAAGGTCGGAGTCAACGGAT & NM_002046 \\
GAPDH & R: CCTGGAAGATGGTGATGGG &
\end{tabular}

F, forward; R, reverse; TNF, tumor necrosis factor; IL, interleukin; iNOS, inducible nitric oxide synthase; COX-2, cyclooxygenase-2.

of each band were quantified using Tanon-5200 Analyzer software. Target protein expression levels were normalized based on the internal controls (GAPDH and Lamin B1).

Statistical analysis. All results are presented as the means \pm standard deviation, and analyzed using one-way analysis of variance followed by Tukey's post hoc test for multiple comparisons with SPSS software (version 22.0; IBM Corp., Armonk, NY, USA). All histograms were plotted using GraphPad Prism 5 software (GraphPad Software, Inc., La Jolla, CA, USA). A value of $\mathrm{P}<0.05$ was considered to indicate a statistically significant difference.

\section{Results}

Effect of TCSGs on $\mathrm{H}_{2} \mathrm{O}_{2}$-induced cytotoxicity in and morphology of LO2 cells. The cell viability data indicated that the TCSGs exerted no significant toxicity towards the L02 cells, even at high concentrations ( $40 \mu \mathrm{g} / \mathrm{ml})$ following treatment for 24 and $48 \mathrm{~h}$. However, TCSGs at the concentrations exceeding $40 \mu \mathrm{g} / \mathrm{ml}$ and treatment for longer than $48 \mathrm{~h}$ markedly decreased cell viability $(\mathrm{P}<0.05$; Fig. $2 \mathrm{~A})$. As shown in Fig. 2B, with increasing concentrations of $\mathrm{H}_{2} \mathrm{O}_{2}$, cell viability decreased in a dose-dependent manner, and the $50 \%$ inhibitory concentration of $\mathrm{H}_{2} \mathrm{O}_{2}$ treatment was $1.49 \mathrm{mM}$, as determined by SPSS software. Based on these results, treatment with 10, 20 and $40 \mu \mathrm{g} / \mathrm{ml}$ TCSGs and $1.5 \mathrm{mM} \mathrm{H}_{2} \mathrm{O}_{2}$, as well as the time points of $48 \mathrm{~h}$ for the TCSGs and $24 \mathrm{~h}$ for $\mathrm{H}_{2} \mathrm{O}_{2}$, were employed in the subsequent experiments. With this selected protocol, the effects of TCSGs on $\mathrm{H}_{2} \mathrm{O}_{2}$-induced cytotoxicity in and morphology of the $\mathrm{L} 02$ cells were investigated. The results revealed that pretreatment with the TCSGs significantly increased the cell survival rate in the cells exposed to $\mathrm{H}_{2} \mathrm{O}_{2}$ (Fig. 2C). As shown in Fig. 2D, the control cells exhibited an irregular polygon morphology, with only a few cells being spindle-shaped. Following exposure to $\mathrm{H}_{2} \mathrm{O}_{2}(1.5 \mathrm{mM})$, the cells became smaller. However, pretreatment with the TCSGs $(10,20$ and $40 \mu \mathrm{g} / \mathrm{ml})$ for $48 \mathrm{~h}$, attenuated the morphological changes of the L02 cells observed with exposure to $\mathrm{H}_{2} \mathrm{O}_{2}$.

Effect of TCSGs on the activities of ALT, AST, LDH and NO levels in LO2 cells. As shown in Fig. 3, exposure to $\mathrm{H}_{2} \mathrm{O}_{2}$ led to a significant elevation in the levels of hepatocellular leakage enzymes, including ALT, AST and LDH, which are indicative of hepatic injury. When compared with the control group, the $\mathrm{NO}$ levels in the group exposed to $\mathrm{H}_{2} \mathrm{O}_{2}$ were markedly increased $(\mathrm{P}<0.01)$. Following pretreatment with the TCSGs, there was a significant attenuation in the activities of ALT, AST and $\mathrm{LDH}$, and the NO levels when compared with the $\mathrm{H}_{2} \mathrm{O}_{2}$ group $(\mathrm{P}<0.05, \mathrm{P}<0.01$ or $\mathrm{P}<0.001)$. The results thus suggested that TCSGs attenuated $\mathrm{H}_{2} \mathrm{O}_{2}$-induced injury in $\mathrm{L} 02$ cells.

Effect of TCSGs on the activities of SOD, CAT and GSH-Px, and MDA levels in LO2 cells. The effects of TCSGs on the activities of SOD, CAT and GSH-Px in the L02 cells are presented in Fig. 4A-C. $\mathrm{H}_{2} \mathrm{O}_{2}$ significantly $(\mathrm{P}<0.001)$ decreased the activities of SOD, CAT and GSH-Px in the L02 cells. However, pretreatment with the TCSGs alleviated the inhibition of antioxidant enzyme activities in a dose-dependent manner under oxidative stress.

The effects of TCSGs on the levels of MDA in the $\mathrm{H}_{2} \mathrm{O}_{2}$-exposed L02 cells are presented in Fig. 4D. Exposure to $\mathrm{H}_{2} \mathrm{O}_{2}$ significantly increased the levels of MDA in the L02 cells when compared with the control group $(\mathrm{P}<0.001)$. However, pretreatment with the TCSGs dose-dependently inhibited the increase in the MDA levels when compared with the $\mathrm{H}_{2} \mathrm{O}_{2}$ group $(\mathrm{P}<0.001)$.

Effect of TCSGs on ROS levels in LO2 cells. The effects of TCSGs on the production of ROS in the $\mathrm{H}_{2} \mathrm{O}_{2}$-exposed L02 cells are presented in Fig. 5B. Exposure to $\mathrm{H}_{2} \mathrm{O}_{2}$ significantly increased intracellular ROS levels in the L02 cells $(\mathrm{P}<0.001)$, and this effect was markedly suppressed by the TCSGs. The results revealed that the TCSGs dose-dependently attenuated $\mathrm{H}_{2} \mathrm{O}_{2}$-induced ROS production in the L02 cells. In addition, each group of images was recorded using a digital camera attached to an inverted fluorescence microscope. As shown in Fig. 5A, the results were in agreement with the fluorescence intensity assays.

Effect of TCSGs on $\mathrm{H}_{2} \mathrm{O}_{2}$-induced production of inflammatory mediators and cytokines in LO2 cells. iNOS and COX-2 are used as inflammatory markers and play critical roles in the 

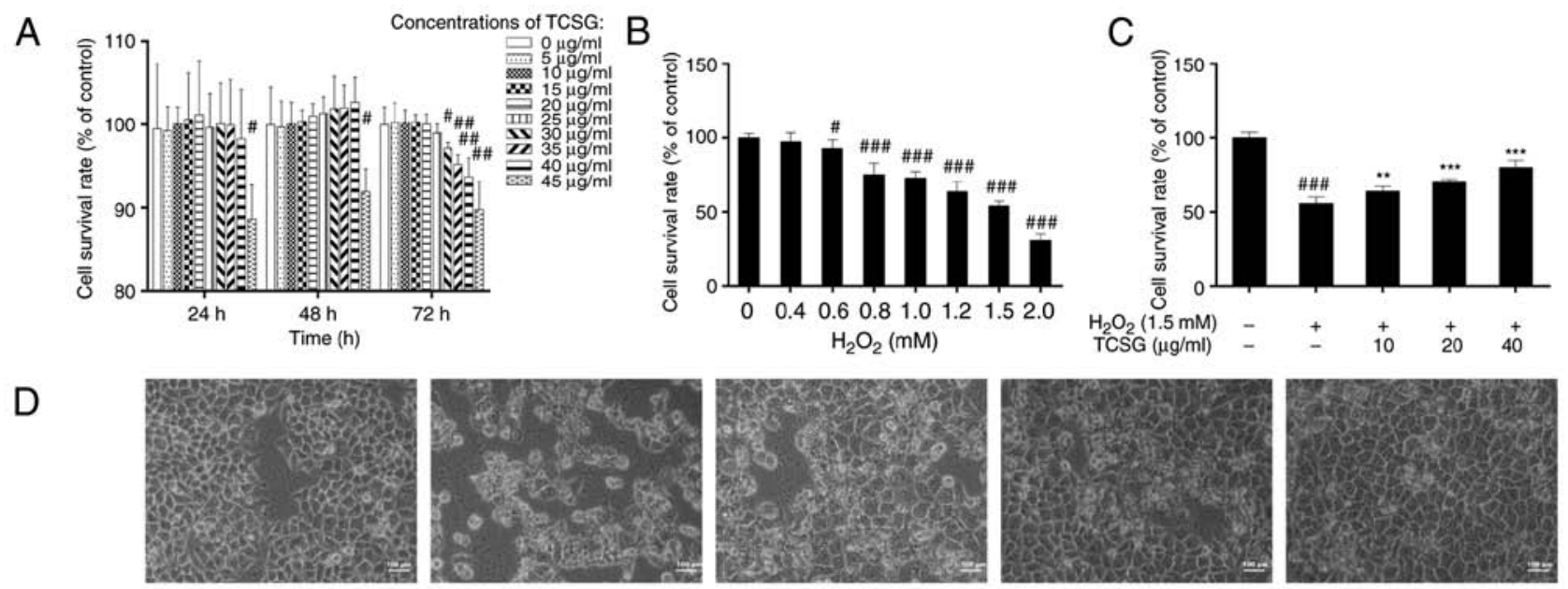

$\mathrm{H}_{2} \mathrm{O}_{2}(1.5 \mathrm{mM})$
TCSG ( $\mu \mathrm{g} / \mathrm{ml})$

$$
+
$$

$\stackrel{+}{10}$

$\stackrel{+}{20}$

$\stackrel{+}{40}$

Figure 2. Effect of TCSGs and $\mathrm{H}_{2} \mathrm{O}_{2}$ on $\mathrm{L02}$ cell morphological changes and cell viability. (A) Cells were treated with the TCSGs $(0,5,10,15,20,25,30$, 35,40 and $45 \mu \mathrm{g} / \mathrm{ml}$ ) for 24, 48 and $72 \mathrm{~h}$. (B) Cells were cultured for $72 \mathrm{~h}$ and then exposed to $\mathrm{H}_{2} \mathrm{O}_{2}(0,0.2,0.4,0.6,0.8,1.0,1.2,1.5$ and $2 \mathrm{mM})$ for $24 \mathrm{~h}$. (C) Pretreatment with TCSGs $(10,20$ and $40 \mu \mathrm{g} / \mathrm{ml})$ for $48 \mathrm{~h}$, followed by treatment with $\mathrm{H}_{2} \mathrm{O}_{2}(1.5 \mathrm{mM})$ for $24 \mathrm{~h}$. (D) L02 cells were cultured with TCSGs $(10,20$ and $40 \mu \mathrm{g} / \mathrm{ml})$ for $48 \mathrm{~h}$, followed by the incubation with $1.5 \mathrm{mM} \mathrm{H}_{2} \mathrm{O}_{2}$ for $24 \mathrm{~h}$. Cell morphology was imaged using an inverted phase contrast microscope (magnification, $\mathrm{x} 200$; scale bar, $100 \mu \mathrm{m})$. All data are presented as the means \pm standard deviation $(\mathrm{n}=6) .{ }^{\#} \mathrm{P}<0.05$, ${ }^{\# \#} \mathrm{P}<0.01$ and ${ }^{\# \# \#} \mathrm{P}<0.001$ vs. the control group $\left(0 ;\right.$ no treatment); ${ }^{* *} \mathrm{P}<0.01$ and ${ }^{* * * *} \mathrm{P}<0.001$ vs. $\mathrm{H}_{2} \mathrm{O}_{2}$ group. TCSGs, total $\mathrm{C}-21$ steroidal glycosides; $\mathrm{H}_{2} \mathrm{O}_{2}$, hydrogen peroxide.
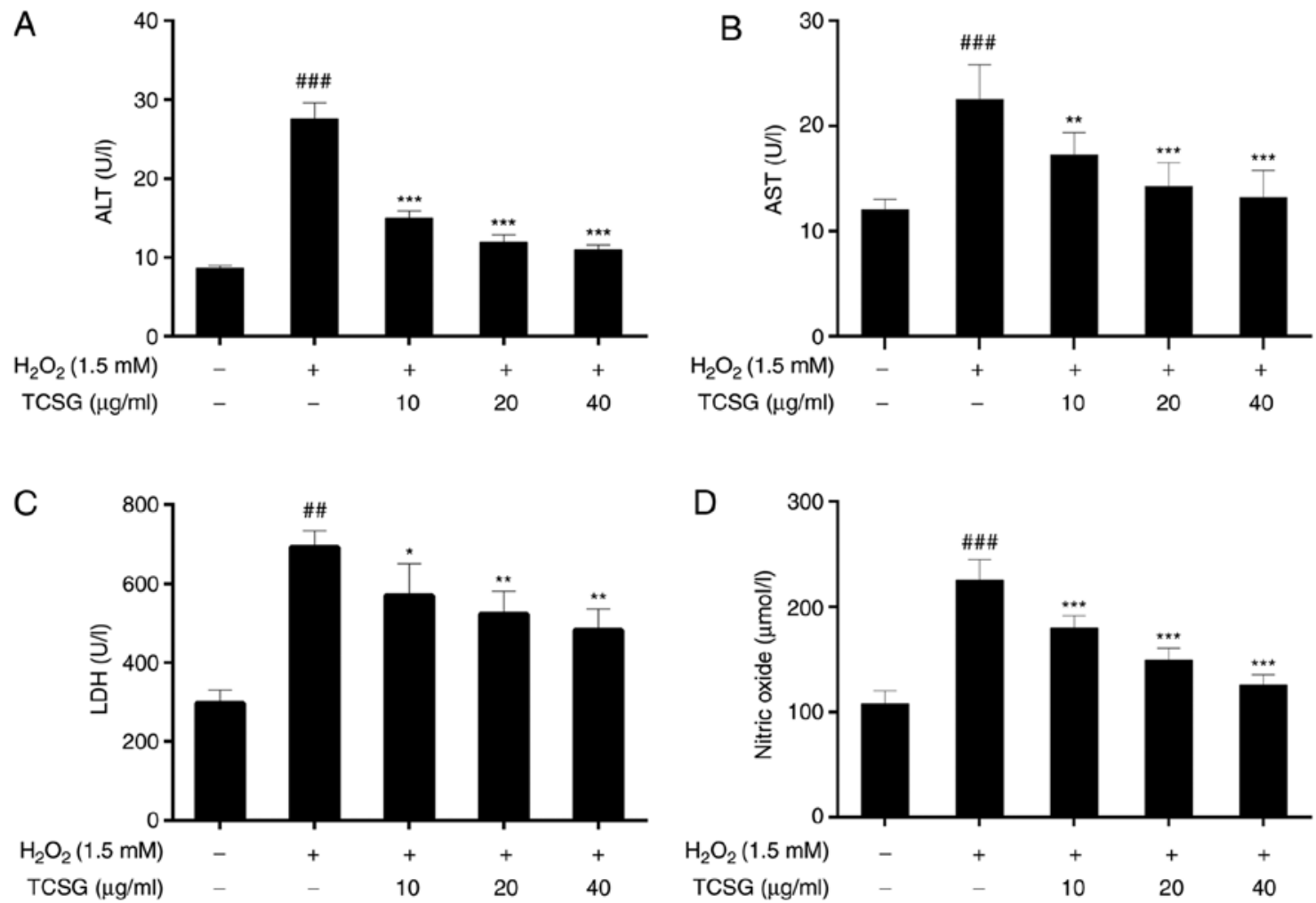

Figure 3. Effect of TCSGs on the supernatant levels of (A) ALT, (B) AST, (C) LDH and (D) NO in $\mathrm{H}_{2} \mathrm{O}_{2}$-exposed L02 cells. Data are expressed as the means \pm standard deviation $(\mathrm{n}=5) .{ }^{\# \#} \mathrm{P}<0.01$ and ${ }^{\# \# \#} \mathrm{P}<0.001$ vs. the control group (no treatment); ${ }^{*} \mathrm{P}<0.05,{ }^{* * *} \mathrm{P}<0.01$ and ${ }^{* * * *} \mathrm{P}<0.001$ vs. $\mathrm{H}_{2} \mathrm{O}_{2}$ group. TCSGs, total C-21 steroidal glycosides; $\mathrm{H}_{2} \mathrm{O}_{2}$, hydrogen peroxide; ALT, alanine aminotransferase; AST, aspartate aminotransferase; LDH, lactate dehydrogenase; $\mathrm{NO}$, nitric oxide.

pathogenesis of chronic inflammation. The effects of TCSGs on the expression levels of iNOS and COX-2 in the L02 cells are presented in Fig. 6. The protein and mRNA expression levels of iNOS (Fig. 6A, B and D) and COX-2 (Fig. 6A, C and D) increased significantly in the $\mathrm{H}_{2} \mathrm{O}_{2}$-exposed group; however, pretreatment with the TCSGs dose-dependently inhibited the increase in the iNOS and COX-2 levels. Furthermore, the results of RT-qPCR demonstrated that the TCSGs markedly attenuated the upregulation in the mRNA expression levels of TNF- $\alpha$ and IL-6 (Fig. 6D) induced by $\mathrm{H}_{2} \mathrm{O}_{2}$ in the L02 cells, 

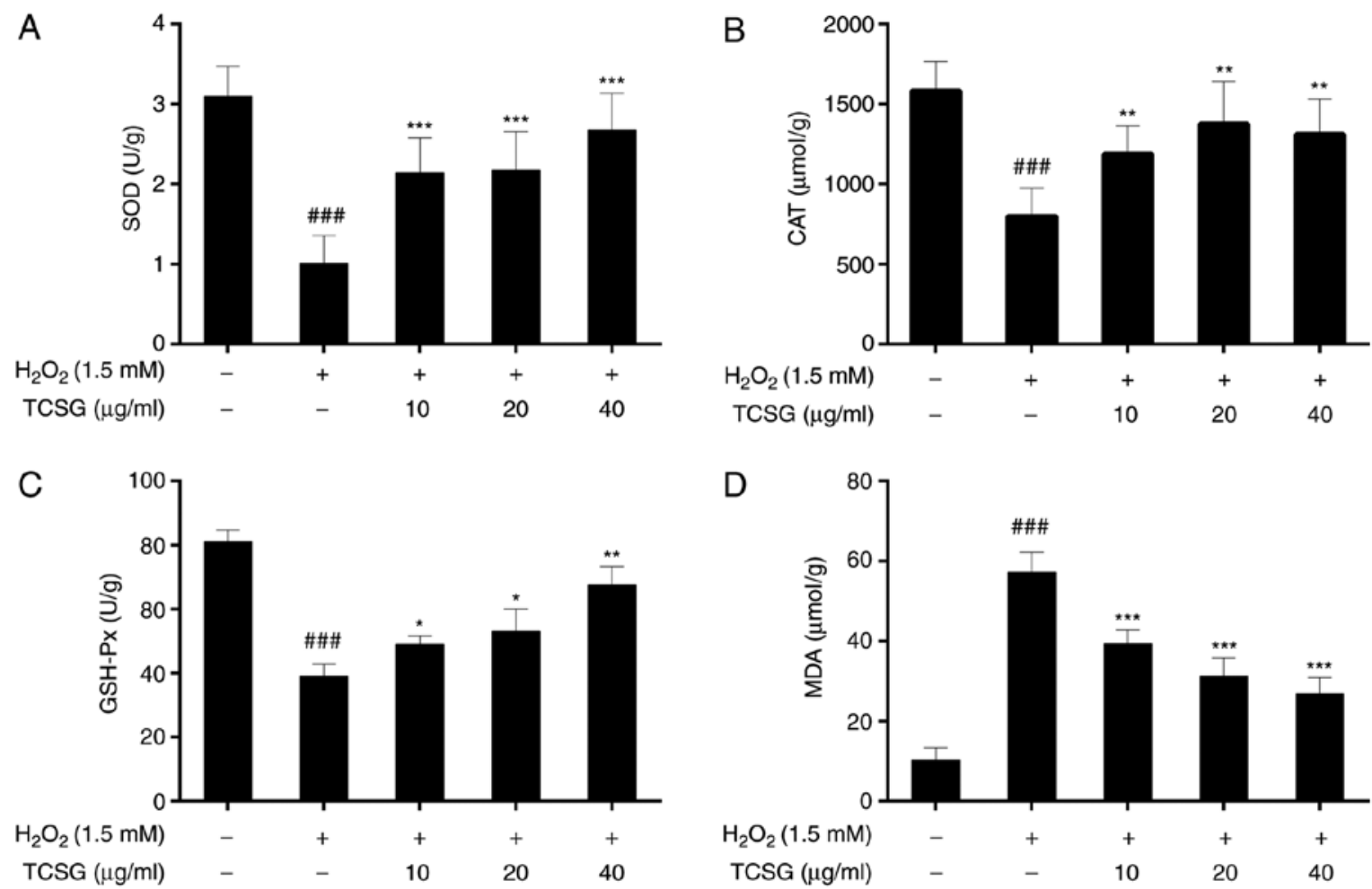

Figure 4. Effect of TCSGs on (A) SOD, (B) CAT, (C) GSH-Px and (D) MDA levels in $\mathrm{H}_{2} \mathrm{O}_{2}$-induced L02 cells. The results are presented as the means \pm standard deviation ( $\mathrm{n}=5)$. ${ }^{\# \# \#} \mathrm{P}<0.001$ vs. the control group (no treatment); ${ }^{*} \mathrm{P}<0.05,{ }^{* * *} \mathrm{P}<0.01$ and ${ }^{* * * *} \mathrm{P}<0.001$ vs. $\mathrm{H}_{2} \mathrm{O}_{2}$ group. TCSGs, total C-21 steroidal glycosides; $\mathrm{H}_{2} \mathrm{O}_{2}$, hydrogen peroxide; SOD, superoxide dismutase; CAT, catalase; GSH-Px, glutathione peroxidase; MDA, malondialdehyde.

which was consistent with the iNOS and COX-2 expression levels mentioned above.

Effect of TCSGs on the Nrf2 signaling pathway in L02 cells. In order to determine the antioxidative mechanisms of action of the TCSGs, the protein expression levels of Nrf2 and $\mathrm{HO}-1$, as well as the translocation of Nrf2 into the nucleus were measured by western blot analysis (Fig. 7). The results revealed that $\mathrm{H}_{2} \mathrm{O}_{2}$ significantly decreased $\mathrm{Nrf} 2$ expression in the cytosol and increased Nrf2 expression in the nucleus, indicating that nuclear Nrf2 translocation had occurred (Fig. 7A, B and D). $\mathrm{H}_{2} \mathrm{O}_{2}$ also downregulated the protein expression of HO-1 in the L02 cells (Fig. 7C). Pretreatment with the TCSGs resulted in the enhanced expression of Nrf2 and HO-1, suggesting that treatment with the TCSGs activated the Nrf2 signaling pathway.

Effect of TCSGs on the activation of the $N F-\kappa B$ signaling pathway in LO2 cells. To further elucidate the mechanisms responsible for the suppression of the inflammatory mediators by the TCSGs in the $\mathrm{H}_{2} \mathrm{O}_{2}$-exposed L02 cells, the NF- $\mathrm{\kappa B}$ signaling pathway was investigated (Fig. 8). It was revealed that pretreatment with the TCSGs dose-dependently downregulated NF- $\mathrm{KB}$ p65 and phospho-NF- $\mathrm{kB}$ p65 levels in the nucleus, and enhanced NF- $\kappa B$ p65 expression in the cytosol in the $\mathrm{H}_{2} \mathrm{O}_{2}$-injured L02 cells (Fig. 8A-C and G). As shown in Fig. 8A and E, the TCSGs significantly inhibited the $\mathrm{H}_{2} \mathrm{O}_{2}$-induced phosphorylation of I $\mathrm{B} \alpha$ in the $\mathrm{L} 02$ cells. These results indicated that the TCSGs prevented the translocation of NF- $\mathrm{KB}$ by inhibiting the phosphorylation of $\mathrm{NF}_{-} \kappa \mathrm{B}$, as well as the degradation and phosphorylation of $\mathrm{I} \kappa \mathrm{B} \alpha$ in the $\mathrm{H}_{2} \mathrm{O}_{2}$-exposed $\mathrm{L} 02$ cells.
Taken together, the potential molecular mechanisms of action of TCSGs in human liver cells and their protective effects against $\mathrm{H}_{2} \mathrm{O}_{2}$-induced oxidative injury and inflammation are presented in Fig. 9.

\section{Discussion}

Hepatic injury is a leading cause of hepatic fibrosis and cancer development. Several factors, including oxidative stress, inflammation and immune responses, have been considered to be involved in the pathogenesis of hepatic injury. An accumulating body of evidence has indicated that oxidative stress and inflammation play important roles in the pathogenesis of liver disease (47). High levels of oxidative stress cause cellular damage, such as lipid peroxidation (48). Inflammatory cytokines also induce oxidant formation and cause liver injury. Anti-oxidative stress-based treatments are promising therapeutic strategies for chronic liver diseases.

TCSGs, the main bioactive components of Baishouwu, have been reported to have potent free radical scavenging properties and hepatoprotective effects $(13,17)$. In the present study, it was confirmed that TCSGs was able to ameliorate $\mathrm{H}_{2} \mathrm{O}_{2}$-induced toxicity in the L02 human hepatic cell line. The results of cell viability assay revealed that treatment with the TCSGs markedly protected the cells from damage caused by $\mathrm{H}_{2} \mathrm{O}_{2}$, and improved the cell survival rate. As shown in Fig. 2B, treatment with TCSGs at a concentration exceeding $40 \mu \mathrm{g} / \mathrm{ml}$ or given or for a prolonged period of time (72 h) seemed to be toxic to the cells. To the best of our knowledge, C-21 steroidal glycosides at higher concentrations may exert cytotoxic effects in vitro (49-52). We speculate the reasons are as follows: 
A
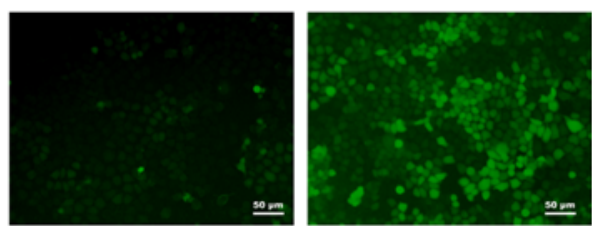

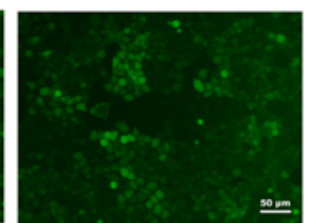

+
-

$\stackrel{+}{10}$

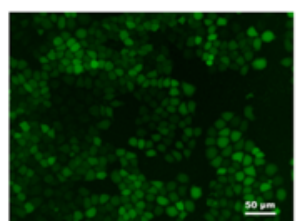

$\stackrel{+}{20}$

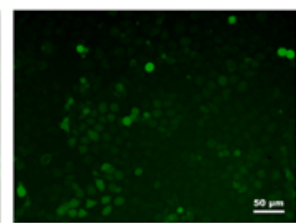

$+$

$\mathrm{H}_{2} \mathrm{O}_{2}(1.5 \mathrm{mM})$

40

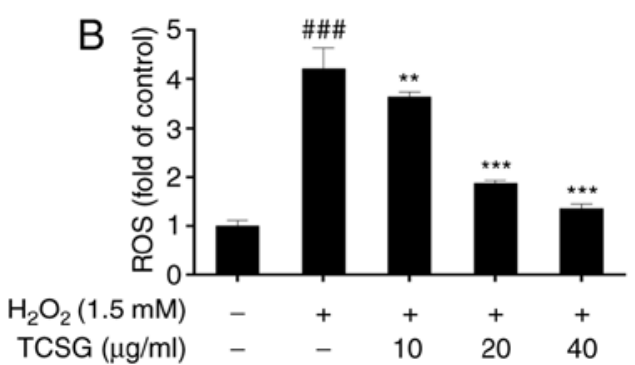

Figure 5. Effect of TCSGs on $\mathrm{H}_{2} \mathrm{O}_{2}$-induced intracellular ROS production in L02 cells. (A) Microphotographs of intracellular ROS levels in $\mathrm{H}_{2} \mathrm{O}_{2}$ stimulated L02 cells were obtained by fluorescence microscopy (magnification, $\mathrm{x} 400$; scale bar, $50 \mu \mathrm{m}$ ). (B) Intracellular ROS production was measured using a fluorescence microplate reader. The results are presented as the means \pm standard deviation $(\mathrm{n}=4) .{ }^{\# \# \#} \mathrm{P}<0.001$ vs. the control group (no treatment); ${ }^{* *} \mathrm{P}<0.01$ and ${ }^{* * * *} \mathrm{P}<0.01$ vs. $\mathrm{H}_{2} \mathrm{O}_{2}$ group. TCSGs, total $\mathrm{C}-21$ steroidal glycosides; $\mathrm{H}_{2} \mathrm{O}_{2}$, hydrogen peroxide; ROS, reactive oxygen species.

A

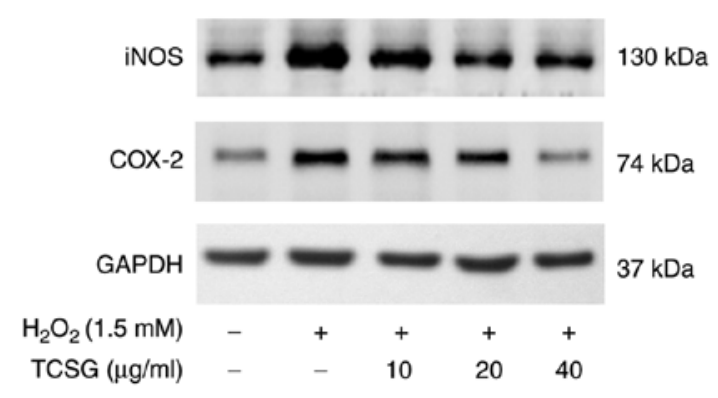

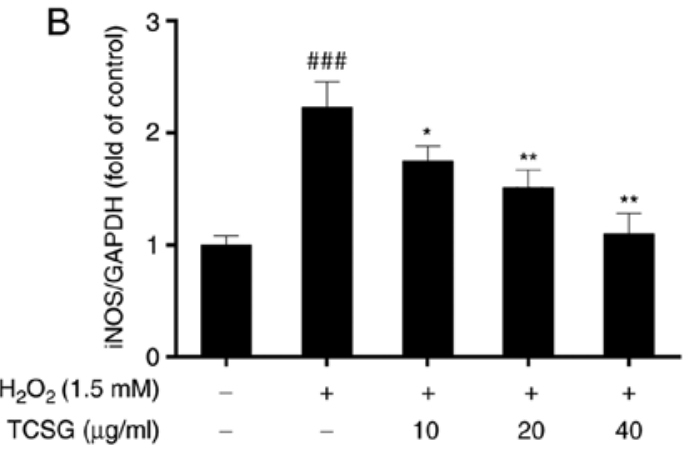

D

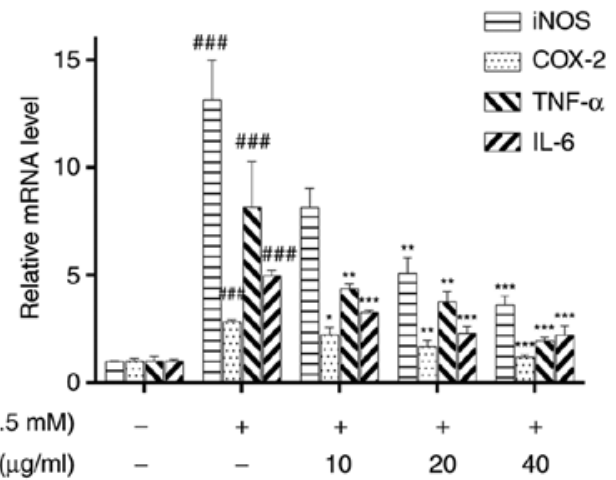

Figure 6. Effect of TCSGs on the $\mathrm{H}_{2} \mathrm{O}_{2}$-induced expression of inflammatory mediators and cytokines in L02 cells. Equal quantities of proteins (50 $\mu \mathrm{g} / \mathrm{lane}$ ) were subjected to $10 \%$ SDS-PAGE, and the protein expression levels of (A) iNOS, COX-2 and GAPDH were detected by western blot analysis in $\mathrm{H}_{2} \mathrm{O}_{2}$-exposed L02 cells. The results of (B) iNOS and (C) COX-2 protein expressions were represented. The mRNA expression levels of (D) iNOS and COX-2 were detected by RT-qPCR in the $\mathrm{H}_{2} \mathrm{O}_{2}$-exposed L02 cells. The mRNA expression levels of (D) TNF- $\alpha$ and IL-6 were detected by RT-qPCR in the $\mathrm{H}_{2} \mathrm{O}_{2}$-exposed L02 cells. All data are presented as the means \pm standard deviation $(\mathrm{n}=3)$. ${ }^{\# \# \#} \mathrm{P}<0.001$ vs. the control group (no treatment); ${ }^{*} \mathrm{P}<0.05,{ }^{* *} \mathrm{P}<0.01$ and ${ }^{* * * *} \mathrm{P}<0.001$ vs. $\mathrm{H}_{2} \mathrm{O}_{2}$ group. TCSGs, total C-21 steroidal glycosides; $\mathrm{H}_{2} \mathrm{O}_{2}$, hydrogen peroxide; RT-qPCR, reverse transcription-quantitative polymerase chain reaction; iNOS, inducible nitric oxide synthase; COX-2, cyclooxygenase-2; TNF, tumor necrosis factor; IL, interleukin.

i) Chemical structures of C-21 steroidal glycosides usually contain hydrophilic and lipophilic groups, which probably affect the cell membrane and produce a surfactant-like action (53); ii) DNA damage may be involved in the cytotoxic mechanisms of C-21 steroidal glycosides. It has been reported that C-21 steroidal glycosides exert growth inhibitory effects on human glioma cells by triggering DNA damage (54). To date, the majority of reports on the cytotoxicity of C-21 steroidal glycosides have mainly focused on tumor cells lines, and few on normal cell lines. From this, it can be deduced that 

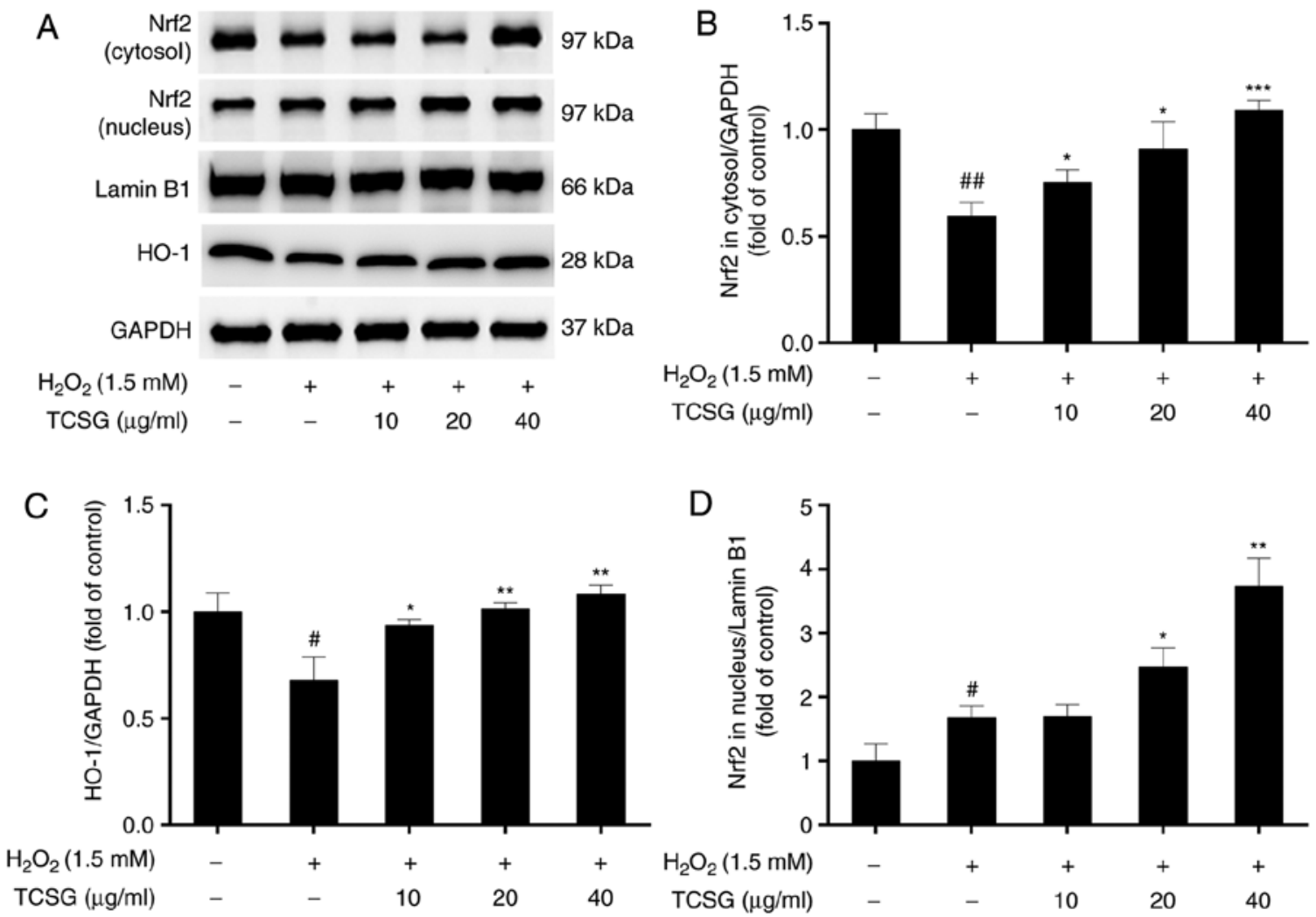

Figure 7. Effect of TCSGs on the protein expression of Nrf2 and HO-1 in L02 cells. Cells were pretreated with the TCSGs (10, 20 and $40 \mu \mathrm{g} / \mathrm{ml})$ for $48 \mathrm{~h}$, stimulated with $\mathrm{H}_{2} \mathrm{O}_{2}(1.5 \mathrm{mM}$ ) for $24 \mathrm{~h}$. The nuclear and cytosolic protein samples were prepared to measure the (A, B and D) Nrf2 in the cytosol and nucleus, and (A and C) HO-1 expression. GAPDH and Lamin B1 served as the internal controls. Results are presented as the means \pm standard deviation (n=3). ${ }^{*} \mathrm{P}<0.05$ and ${ }^{\# \#} \mathrm{P}<0.01$ vs. the control group (no treatment); ${ }^{*} \mathrm{P}<0.05,{ }^{* *} \mathrm{P}<0.01$ and ${ }^{* * * *} \mathrm{P}<0.001$ vs. $\mathrm{H}_{2} \mathrm{O}_{2}$ group. TCSGs, total C-21 steroidal glycosides; $\mathrm{H}_{2} \mathrm{O}_{2}$, hydrogen peroxide; Nrf2, nuclear factor erythroid 2-related factor 2; HO-1, heme oxygenate-1.

the cytotoxic effects of C-21 steroidal glycosides on normal cells may differ from those on cancer cell lines. Thus, in the future, we aim to carry out further investigations on the cytotoxic effects and mechanisms of action of C-21 steroidal glycosides.

Oxidative stress leads to cellular damage and cell death via the generation of ROS. Excess ROS primarily induces lipid peroxidation, as indicated by the production of MDA. MDA is a critical marker of lipid peroxidation and is one of the final products of the peroxidation of unsaturated fatty acids. The levels of MDA reflect the extent of cell oxidative damage (55). The antioxidant defense system, containing SOD, CAT, and GSH-Px, scavenges ROS to prevent cell damage in response to oxidative stress $(56,57)$. The present study demonstrated that the enzyme activities of SOD, CAT and GSH-Px, decreased following exposure to $\mathrm{H}_{2} \mathrm{O}_{2}$. In addition, the ROS levels and MDA levels increased in the L02 cells exposed to $\mathrm{H}_{2} \mathrm{O}_{2}$. However, treatment with the TCSGs attenuated these effects. The results indicated that TCSGs inhibited $\mathrm{H}_{2} \mathrm{O}_{2}$-induced oxidative damage by suppressing ROS production and lipid peroxidation, and enhancing the antioxidant defense systems.

The pro-inflammatory enzymes, iNOS and COX-2, play important roles in liver damage. The activation of iNOS induces the production of high levels of NO and further damages hepatocytes $(58,59)$. The present study demonstrated that the TCSGs significantly inhibited COX-2 and iNOS expression, which was consistent with the reduced NO levels in the $\mathrm{L} 02$ cells exposed to $\mathrm{H}_{2} \mathrm{O}_{2}$ but pretreated with the TCSGs. It has been reported that the upregulation in the mRNA levels of iNOS and COX-2 in hepatic tissues and cells is a result of the increased expression of pro-inflammatory cytokines, such as TNF- $\alpha$ and IL- 6 , and the activation of NF- $\mathrm{KB}(60,61)$. Cytokines, including TNF- $\alpha$ and IL- 6 have been the focus of previous investigations evaluating the inflammatory injury of tissues or cells, as they activate the inflammatory and immune responses, exacerbating hepatic injury (62). The results of the present study revealed that the increased levels of TNF- $\alpha$ and IL-6 induced by $\mathrm{H}_{2} \mathrm{O}_{2}$ were markedly suppressed by pretreatment with the TCSGs. Notably, treatment with the TCSGs also markedly downregulated the expression of NF- $\kappa \mathrm{B}$ p65 and $\mathrm{p}-\mathrm{NF}-\kappa \mathrm{B}$ p 65 in the nucleus, upregulated NF- $\kappa \mathrm{B}$ p65 expression in the cytosol, and reduced the degradation and phosphorylation of $\mathrm{I} \kappa \mathrm{B} \alpha$ induced by $\mathrm{H}_{2} \mathrm{O}_{2}$ in the L- 02 cells. Oxidative stress is known to activate NF- $\kappa \mathrm{B}$, leading to the induction of inflammatory genes, which in turn increases neutrophil recruitment to the liver and exacerbates oxidative stress and inflammation. Taken together, the results of the present study indicated that TCSGs exerted hepatoprotective effects against $\mathrm{H}_{2} \mathrm{O}_{2}$-induced oxidative stress via the inhibition of the NF- $\kappa \mathrm{B}$ signaling pathway and the reduction in COX-2 and iNOS levels, resulting in the reduction of inflammatory factors.

Nrf2 is a pivotal transcription factor, which can encode detoxification enzymes and antioxidant proteins to against oxidative stress (63). Nrf2 regulates the expression of various 


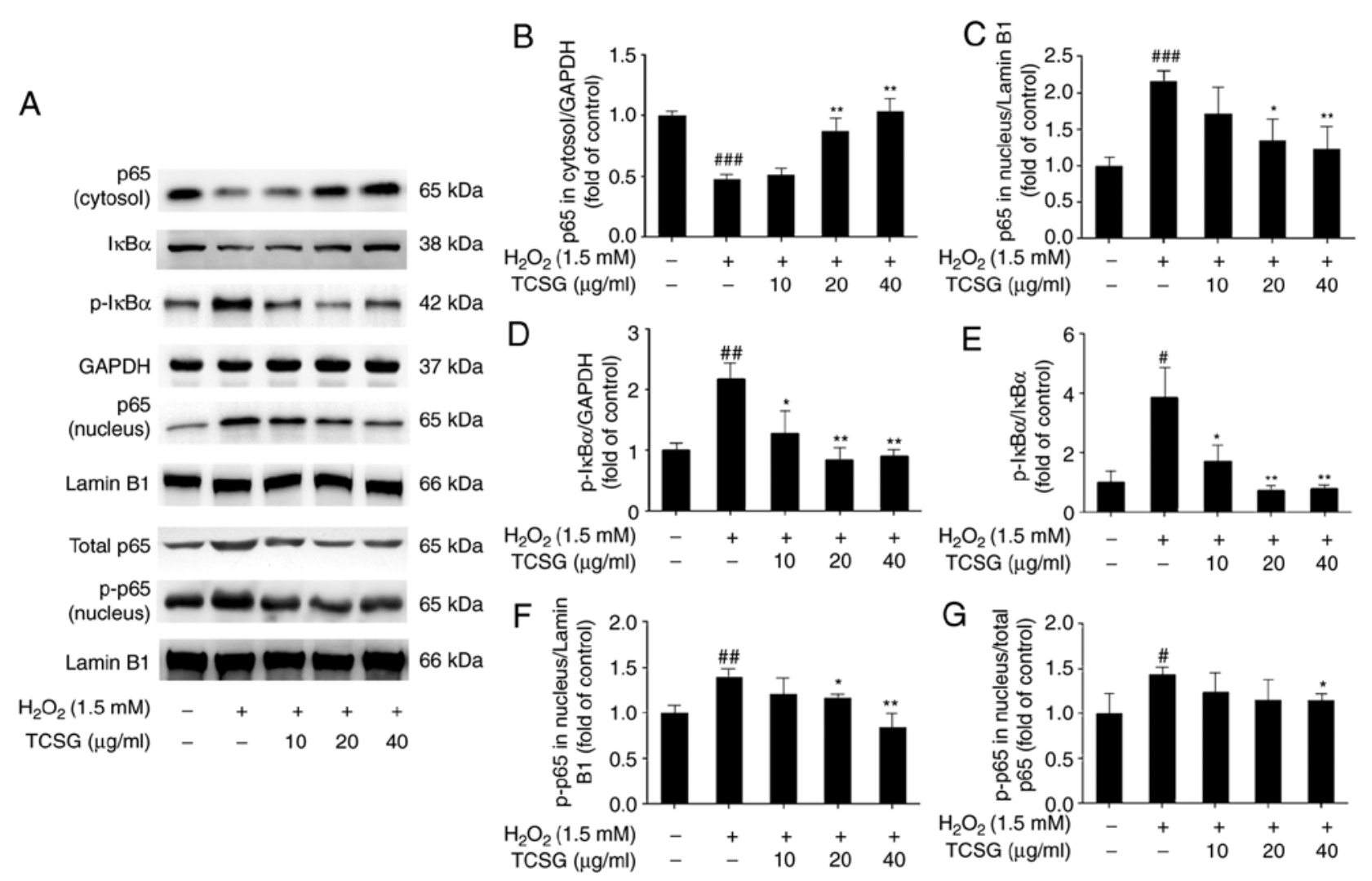

Figure 8. Effect of TCSGs on the activation of the NF- $\mathrm{KB}$ signaling pathway in $\mathrm{H}_{2} \mathrm{O}_{2}$-induced L02 cells. Cells were pretreated with the TCSGs (10, 20 and $40 \mu \mathrm{g} / \mathrm{ml})$ for $48 \mathrm{~h}$, and stimulated with $\mathrm{H}_{2} \mathrm{O}_{2}(1.5 \mathrm{mM})$ for $24 \mathrm{~h}$. The samples of nuclear and cytosolic proteins were prepared to detect the expression of

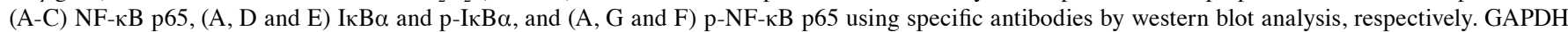
and Lamin B1 were used as the internal controls. All results are presented as the means \pm standard deviation $(\mathrm{n}=3) .{ }^{\#} \mathrm{P}<0.05$, ${ }^{\# \#} \mathrm{P}<0.01$ and ${ }^{\# \# \#} \mathrm{P}<0.001$ vs. the control group (no treatment); ${ }^{*} \mathrm{P}<0.05$ and ${ }^{* *} \mathrm{P}<0.01$ vs. $\mathrm{H}_{2} \mathrm{O}_{2}$ group. TCSGs, total $\mathrm{C}-21$ steroidal glycosides; $\mathrm{H}_{2} \mathrm{O}_{2}$, hydrogen peroxide; NF- $\kappa \mathrm{B}$, nuclear factor- $\kappa \mathrm{B}$; $\mathrm{I} \kappa \mathrm{B} \alpha$, inhibitor of nuclear factor- $\mathrm{\kappa} \mathrm{B} \alpha ; \mathrm{p}-$, phosphorylated.

antioxidant enzymes, including CAT, GSH-Px, and SOD, by using GSH as their substrate (64). The activation of Nrf2 in cells provides an indirect strategy to enhance antioxidative capacity $(65,66)$. Under oxidative stress conditions, Nrf2 is released from Kelch-like ECH-associated protein 1 and translocates to the nucleus; it then recognizes the ARE and regulates the expression of antioxidant enzymes including HO-1. In the present study, the antioxidant ability of TCSGs in the regulation of redox mechanisms by augmenting the expression of antioxidant genes via the $\mathrm{Nrf} 2$ signaling pathway, was evaluated. Following exposure to $\mathrm{H}_{2} \mathrm{O}_{2}$, Nrf2 expression in the $\mathrm{L} 02$ cells decreased in the cytoplasm, but increased in the nucleus when compared with the control group, which indicated that the nuclear Nrf2 translocation and Nrf2 activation had occurred. To the best of our knowledge, the effects of $\mathrm{H}_{2} \mathrm{O}_{2}$ on $\mathrm{Nrf} 2$ activation are strongly dependent on $\mathrm{H}_{2} \mathrm{O}_{2}$ concentrations and the method of $\mathrm{H}_{2} \mathrm{O}_{2}$ delivery (67). Different results however, have been obtained under different experimental conditions. Ma et al reported that treatment with $200 \mu \mathrm{M} \mathrm{H}_{2} \mathrm{O}_{2}$ for 30 min exerted no significant effect on the cytosolic Nrf2 expression in HepG2 cells (68). In addition, in another study, no significant influence on the expression of nuclear Nrf2 was observed in melanocyte cells exposed to $1 \mathrm{mM} \mathrm{H}_{2} \mathrm{O}_{2}$ for $24 \mathrm{~h}$ (69). Some researchers have proven that the nuclear Nrf2 translocation occurs in melanocytes or human dental pulp stem cells following exposure to $\mathrm{H}_{2} \mathrm{O}_{2}(36,70)$. Other studies have found that exposure to $300 \mu \mathrm{M} \mathrm{H}_{2} \mathrm{O}_{2}$ for $4 \mathrm{~h}$ significantly decreased the expression of Nrf2 at both the mRNA and protein level in PC12 cells (71). In this study, $\mathrm{H}_{2} \mathrm{O}_{2}$ decreased Nrf2 expression in the cytoplasm and increased it in the nucleus, which indicated that nuclear Nrf2 translocation and Nrf2 activation occurred. It was speculated that Nrf2 may have been slightly activated as an adaptive defense against oxidative stress under these conditions. In the groups treated with the TCSGs, Nrf2 expression and the translocation of Nrf2 into the nucleus were markedly increased when compared with the $\mathrm{H}_{2} \mathrm{O}_{2}$ group, indicating that there was an enhanced activation of the Nrf2 signaling pathway. Furthermore, the TCSGs markedly upregulated the expression of downstream target proteins of the Nrf2 signaling pathway, such as HO-1. HO-1 is a key rate-limiting enzyme in the degradation of heme, preventing free heme from participating in the oxidative reaction. The overexpression of HO-1 inhibited ROS generation, NF- $\mathrm{KB}$ activation and nuclear translocation, and protected against oxidative stress and inflammatory injury (72). Combined with the findings of the present study, these results demonstrated that TCSGs protected $\mathrm{L} 02$ cells against $\mathrm{H}_{2} \mathrm{O}_{2}$-mediated oxidative injury by activating the Nrf2 signaling pathway and inducing HO-1 expression.

In conclusion, in this study, it was demonstrated that pretreatment with the TCSGs protected the $\mathrm{L} 02$ cells against $\mathrm{H}_{2} \mathrm{O}_{2}$-induced oxidative damage by increasing the expression of $\mathrm{Nrf} 2$ and HO-1, medicated by the NF- $\mathrm{KB}$ signaling pathway. The present study also indicated that TCSGs isolated from Baishouwu 


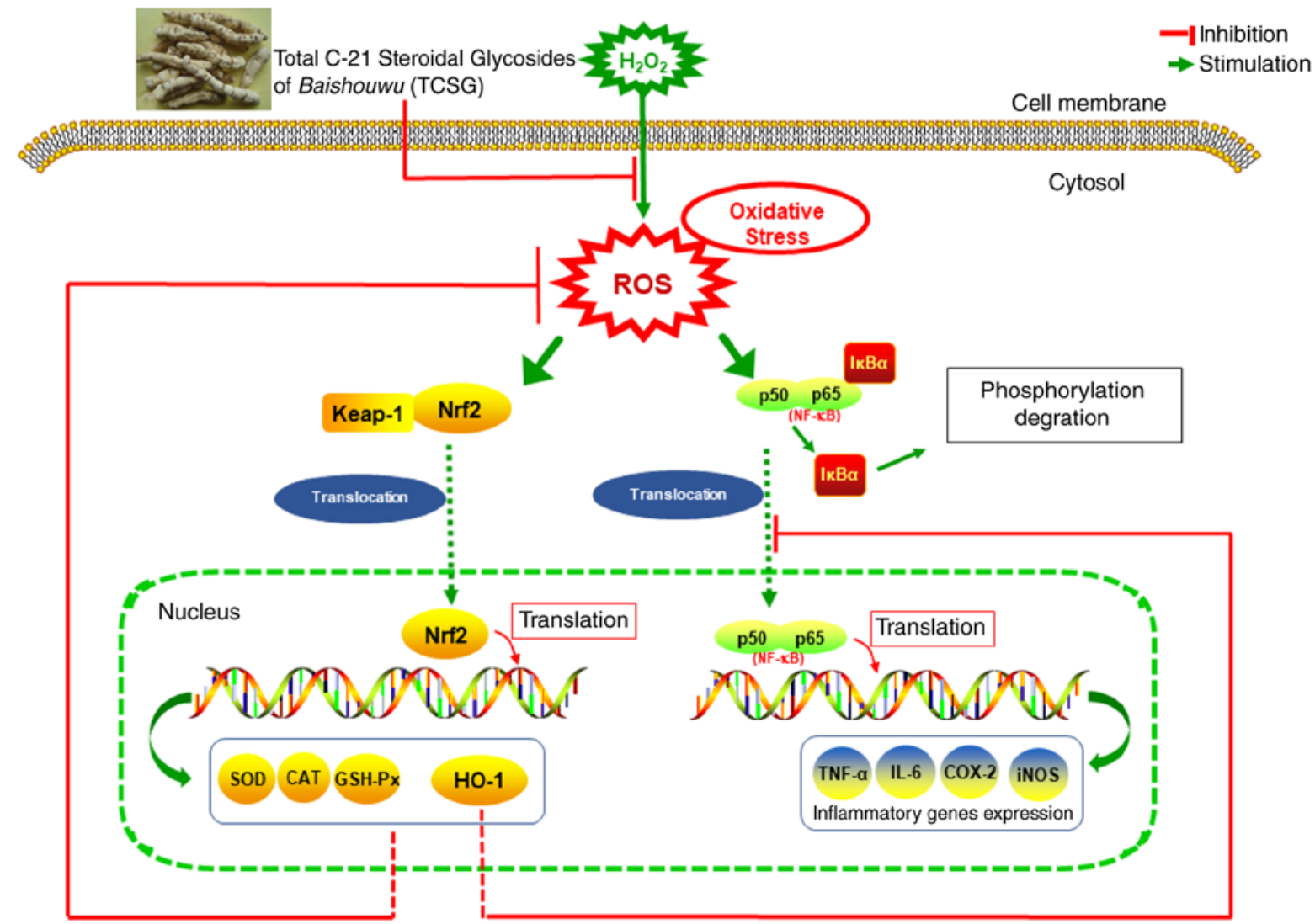

Figure 9. A schematic illustration of the potential molecular mechanism underlying the TCSGs attenuation of oxidative stress and inflammation in L02 cells via

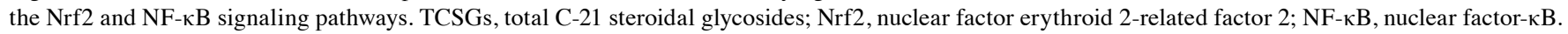

possessed marked anti-oxidative stress and anti-inflammatory effects against $\mathrm{H}_{2} \mathrm{O}_{2}$-induced hepatic injury via $\mathrm{Nrf} 2$ activation and inhibition of the NF- $\kappa \mathrm{B}$ signaling pathway (Fig. 9). Further studies on the potential effects of TCSGs on any other cell signaling pathways involved in the pathogenesis of $\mathrm{H}_{2} \mathrm{O}_{2}$-induced hepatotoxicity are still ongoing. Based on these results, TCSGs may be proven to be a promising strategy for preventing inflammation and reducing the risk of hepatic disease.

\section{Acknowledgements}

Not applicable.

\section{Funding}

The present study was supported by the National Natural Science Foundation of China (grant nos. 81774178, 81373888 and 81102884) and Jiangsu Province Natural Science Foundation of China (grant no. BK20151606).

\section{Availability of data and materials}

The datasets used and/or analyzed during the current study are available from the corresponding author on reasonable request.

\section{Authors' contributions}

PW and YP designed the experiments. ZW, YWa and $\mathrm{XM}$ performed the experiments. XW, ZL and SQ equally contributed in extraction and analysis of chemical constituents. YWe, LS and YD analyzed the results. ZW drafted the manuscript. All the authors read and approved the final manuscript.

\section{Ethics approval and consent to participate}

Not applicable.

\section{Patient consent for publication}

Not applicable.

\section{Competing interests}

The authors confirm that they have no competing interests.

\section{References}

1. Shan L, Liu RH, Shen YH, Zhang WD, Zhang C, Wu DZ, Min L, $\mathrm{Su} \mathrm{J}$ and $\mathrm{Xu} \mathrm{XK}$ : Gastroprotective effect of a traditional Chinese herbal drug 'Baishouwu' on experimental gastric lesions in rats. J Ethnopharmacol 107: 389-394, 2006.

2. Li Y, Zhang J, Gu X, Peng Y, Huang W and Qian S: Two new cytotoxic pregnane glycosides from Cynanchum auriculatum. Planta Med 74: 551-554, 2008.

3. Wang DY, Hua X, Ye JL, Li JJ, Li Q and Yan HS: Antitumor effect of C21 steroidal glycosides in Radix Cynanchi bungei on Heps rats and its influence on hematopoiesis. J Clin Med Pract 18: 6-8, 2014.

4. Peng YR, Li YB, Liu XD, Zhang JF and Duan JA: Antitumor activity of C-21 steroidal glycosides from Cynanchum auriculatum Royle ex Wight. Phytomedicine 15: 1016-1020, 2008. 
5. Zhang RS, Ye YP and Liu XL: Studies on in vitro antitumor activity of total steroidal glycoside from the root of Cynanchum auriculatum. Chin Tradit Herbal Drugs 31: 599-601, 2000.

6. Zhang RS, Ye YP, Shen YM and Liang HL: Two new cytotoxic C-21 steroidal glycosides from the root of Cynanchum auriculatum. Tetrahedron 56: 3875-3879, 2000.

7. Wang YQ, Zhang SJ, Lu H, Yang B, Ye LF and Zhang RS: A C21-steroidal glycoside isolated from the roots of Cynanchum auriculatum induces cell cycle arrest and apoptosis in human gastric cancer SGC-7901 cells. Evid Based Complement Alternat Med 2013: 180839, 2013.

8. Wang DY, Zhang HQ and Li X: Apoptosis induced by the C21 sterols in Baishouwu and its mechanism of action in hepatoma. Yao Xue Xue Bao 42: 366-370, 2007 (In Chinese).

9. Shan L, Zhang WD, Zhang C, Liu RH, Su J and Zhou Y: Antitumor activity of crude extract and fractions from root tuber of Cynanchum auriculatum Royle ex Wight. Phytother Res 19: 259-261, 2005.

10. Peng YR, Li YB, Liu XD, Zhang JF and Duan JA: Apoptosis induced by caudatin in human hepatoma cell line SMMC7721. Chin J Nat Med 6: 210-213, 2008

11. Peng YR, Ding YF, Wei YJ, Shu B, Li YB and Liu XD: Caudatin2,6-dideoxy-3-O-methy- $\beta$-D-cymaropyranoside 1 induced apoptosis through caspase 3-dependent pathway in human hepatoma cell line SMMC7721. Phytother Res 25: 631-637, 2011.

12. Zhang SX, Li X, Yin JL, Chen LL and Zhang HQ: Effect of C21 steroidal glycoside from root of Cynanchum auriculatum on $\mathrm{D}$-galactose induced aging model mice. Zhongguo Zhong Yao Za Zhi 32: 2511-2514, 2007 (In Chinese).

13. Song JM and Ding XL: Study on the scavenging effect of Baishouwu on superoxide free radicals. Chin Wild Plant Resources 17: 1-4, 1997.

14. Gu LG, Gong SS, Tao JD, Liu CH and Zhou Y: Studies on the regulation effect of Baishouwu on the immunity of mouse. Chin J Int Med 7: 37-41, 1987.

15. Ji CX, Li XY, Jia SB, Liu LL, Ge YC, Yang QX and Zhang JJ: The antidepressant effect of Cynanchum auriculatum in mice. Pharm Biol 50: 1067-1072, 2012.

16. Yoon MY, Choi NH, Min BS, Choi GJ, Choi YH, Jang KS, Han SS, Cha B and Kim JC: Potent in vivo antifungal activity against powdery mildews of pregnane glycosides from the roots of Cynanchum wilfordii. J Agric Food Chem 59: 12210-12216, 2011.

17. Lv W, Zhang A, Xu S and Zhang H: Effects of general glycosides in Cynanchum auriculatum of Jiangsu province on liver fibrosis of rats. Zhongguo Zhong Yao Za Zhi 34: 2508-2511, 2009 (In Chinese)

18. Jaeschke H: Reactive oxygen and mechanisms of inflammatory liver injury: Present concepts. J Gastroenterol Hepatol 26 (Suppl 1) S173-S179, 2011

19. Miller AM, Wang H, Park O, Horiguchi N, Lafdil F, Mukhopadhyay P, Moh A, Fu XY, Kunos G, Pacher P and Gao B: Anti-inflammatory and anti-apoptotic roles of endothelial cell STAT3 in alcoholic liver injury. Alcohol Clin Exp Res 34: 719-725, 2010

20. Dey A and Cederbaum AI: Alcohol and oxidative liver injury. Hepatology 43 (Suppl 1): S63-S74, 2006.

21. Sies H, Berndt C and Jones DP: Oxidative stress. Annu Rev Biochem 86: 715-748, 2017

22. Weng D, Lu Y, Wei Y, Liu Y and Shen P: The role of ROS in microcystin-LR-induced hepatocyte apoptosis and liver injury in mice. Toxicology 232: 15-23, 2007.

23. Tsukiyama-Kohara K: Role of oxidative stress in hepatocarcinogenesis induced by hepatitis $\mathrm{C}$ virus. Int $\mathrm{J}$ Mol Sci 13 : 15271-15278, 2012.

24. Das S, Maras JS, Hussain MS, Sharma S, David P, Sukriti S, Shasthry SM, Maiwall R, Trehanpati N, Singh TP and Sarin SK Hyperoxidized albumin modulates neutrophils to induce oxidative stress and inflammation in severe alcoholic hepatitis. Hepatology 65: 631-646, 2017

25. Chen G, Ni Y, Nagata N, Xu L and Ota T: Micronutrient antioxidants and nonalcoholic fatty liver disease. Int J Mol Sci 17: pii: E1379, 2016

26. Wang M, Ma HL, Liu B, Wang HB, Xie H, Li RD and Wang JF: Pinus massoniana bark extract protects against oxidative damage in L-02 hepatic cells and mice. Am J Chin Med 38: 909-919, 2010.

27. Sies H: Hydrogen peroxide as a central redox signaling molecule in physiological oxidative stress: Oxidative eustress. Redox Biol 11: 613-619, 2017.
28. Hseu YC, Wu FY, Wu JJ, Chen JY, Chang WH, Lu FJ, Lai YC and Yang HL: Anti-inflammatory potential of Antrodia Camphorata through inhibition of iNOS, COX-2 and cytokines via the NF-kappaB pathway. Int Immunopharmacol 5: 1914-1925, 2005.

29. Lee D, Park S, Bae S, Jeong D, Park M, Kang C, Yoo W, Samad MA, Ke Q, Khang G and Kang PM: Hydrogen peroxideactivatable antioxidant prodrug as a targeted therapeutic agent for ischemia-reperfusion injury. Sci Rep 5: 16592, 2015.

30. Li W and Kong AN: Molecular mechanisms of Nrf2-mediated antioxidant response. Mol Carcinog 48: 91-104, 2009.

31. Yu J, Zhu X, Qi X, Che J and Cao B: Paeoniflorin protects human EA.hy926 endothelial cells against gamma-radiation induced oxidative injury by activating the NF-E2-related factor 2 /heme oxygenase-1 pathway. Toxicol Lett 218: 224-234, 2013

32. Shin SM, Yang JH and Ki SH: Role of the Nrf2-ARE pathway in liver diseases. Oxid Med Cell Longev 2013: 763257, 2013.

33. Huo X, Liu C, Gao L, Xu X, Zhu N and Cao L: Hepatoprotective effect of aqueous extract from the seeds of orychophragmus violaceus against liver injury in mice and HepG2 cells. Int J Mol Sci 18: pii: E1197, 2017.

34. Conde de la Rosa L, Schoemaker MH, Vrenken TE, Buist-Homan M, Havinga R, Jansen PL and Moshage H: Superoxide anions and hydrogen peroxide induce hepatocyte death by different mechanisms: Involvement of JNK and ERK MAP kinases. J Hepatol 44: 918-929, 2006.

35. Vaziri ND: Oxidative stress in uremia: Nature, mechanisms, and potential consequences. Semin Nephrol 24: 469-473, 2004.

36. Kim D, Kim H, Kim K and Roh S: The protective effect of indole-3-acetic acid (IAA) on $\mathrm{H} 2 \mathrm{O} 2$-damaged human dental pulp stem cells is mediated by the AKT pathway and involves increased expression of the transcription factor nuclear factor-erythroid 2-related factor 2 (Nrf2) and its downstream target heme oxygenase 1 (HO-1). Oxid Med Cell Longev 2017: 8639485, 2017.

37. Cao YJ, Zhang YM, Qi JP, Liu R, Zhang H and He LC: Ferulic acid inhibits $\mathrm{H} 2 \mathrm{O} 2$-induced oxidative stress and inflammation in rat vascular smooth muscle cells via inhibition of the NADPH oxidase and NF-кB pathway. Int Immunopharmacol 28: 1018-1025, 2015

38. Tian Y, Li Z, Shen B, Zhang Q and Feng H: Protective effects of morin on lipopolysaccharide/d-galactosamine-induced acute liver injury by inhibiting TLR4/NF- $\mathrm{KB}$ and activating Nrf2/HO-1 signaling pathways. Int Immunopharmacol 45: 148-155, 2017.

39. Tan ZW, Xie S, Hu SY, Liao T, Liu P, Peng KH, Yang XZ, He ZL, Tang HY, Cui Y, et al: Caudatin targets TNFAIP1/NF- $\kappa$ B and cytochrome c/caspase signaling to suppress tumor progression in human uterine cancer. Int J Oncol 49: 1638-1650, 2016.

40. Gu XJ, Yao N, Qian SH, Li YB and Li P: Four new C21 steroidal glycosides from the root of Cynanchum auriculatum. Helvetica Chimica Acat 92: 88-97, 2009 .

41. Wang XJ, Li ZL, Lv XH, Zuo QY, Zhao YM, Ding YF, Pu SB, Qian SH and Peng YR: Antitumor evaluation and multiple analysis on different extracted fractions of the root of Cynanchum auriculatum Royle ex Wight. J Sep Sci 40: 3054-3063, 2017.

42. Zhao YN, Wang ZL, Dai JG, Chen L and Huang YF: Preparation and quality assessment of high-purity ginseng total saponins by ion exchange resin combined with macroporous adsorption resin separation. Chin J Nat Med 12: 382-392, 2014.

43. Hu X, Yang T, Li C, Zhang L, Li M, Huang W and Zhou P: Human fetal hepatocyte line, L-02, exhibits good liver function in vitro and in an acute liver failure model. Transplant Proc 45: 695-700, 2013.

44. Myhre O, Andersen JM, Aarnes H and Fonnum F: Evaluation of the probes 2 ',7'-dichlorofluorescin diacetate, luminol, and lucigenin as indicators of reactive species formation. Biochem Pharmacol 65: 1575-1582, 2003.

45. Ding YF, Wu ZH, Wei YJ, Shu L and Peng YR: Hepatic inflammation-fibrosis-cancer axis in the rat hepatocellular carcinoma induced by diethylnitrosamine. J Cancer Res Clin Oncol 143: 821-834, 2017.

46. Livak KJ and Schmittgen TD: Analysis of relative gene expression data using real-time quantitative PCR and the 2(-Delta Delta C(T)) method. Methods 25: 402-408, 2001

47. Wei Y, Chen K, Whaley-Connell AT, Stump CS, Ibdah JA and Sowers JR: Skeletal muscle insulin resistance: Role of inflammatory cytokines and reactive oxygen species. Am J Physiol Regul Integr Comp Physiol 294: R673-R680, 2008.

48. Sid B, Verrax J and Calderon PB: Role of oxidative stress in the pathogenesis of alcohol-induced liver disease. Free Radic Res 47: 894-904, 2013 
49. Dong J, Peng X, Li L, Lu S, Zhou L and Qiu M: C21 steroidal glycosides with cytotoxic activities from Cynanchum otophyllum. Bioorg Med Chem Lett 28: 1520-1524, 2018.

50. Wang YQ, Yang B, Zhang RS and Wei EQ: Inhibitive effect of C-21 steroidal glycosides of Cynanchum auriculatum on rat glioma cells in vitro. Zhejiang Da Xue Xue Bao Yi Xue Ban 40: 402-407, 2011 (In Chinese).

51. Wang YB, Su SS, Chen SF, Tang MX, Chen G, Zhao D, Sang XN, Si YY, Wang HF and Pei YH: C 21 steroidal glycosides with cytotoxic activity from Cynanchum taihangense. Phytochem Lett 20: 218-223, 2017.

52. Kim CS, Ju YO, Sang UC and Lee KR: Chemical constituents from the roots of Cynanchum paniculatum, and their cytotoxic activity. Carbohydr Res 381: 1-5, 2013.

53. Wang DY and Zhang HQ: The current situation and progress of Baishouwu planted in Jiangsu. Chin Wild Plant Resources 24: 13-15, 2005.

54. Fu XY, Zhang S, Wang K, Yang MF, Fan CD and Sun BL: Caudatin inhibits human glioma cells growth through triggering DNA damage-mediated cell cycle arrest. Cell Mol Neurobiol 35: 953-959, 2015.

55. Su M, Yu T, Zhang H, Wu Y, Wang X and Li G: The antiapoptosis effect of glycyrrhizate on HepG2 cells induced by hydrogen peroxide. Oxid Med Cell Longev 2016: 6849758, 2016.

56. Zhao L, Chen J, Su J, Li L, Hu S, Li B, Zhang X, Xu Z and Chen T: In vitro antioxidant and antiproliferative activities of 5-hydroxymethylfurfural. J Agric Food Chem 61: 10604-10611, 2013.

57. Herken H, Uz E, Ozyurt H, Söğüt S, Virit O and Akyol O: Evidence that the activities of erythrocyte free radical scavenging enzymes and the products of lipid peroxidation are increased in different forms of schizophrenia. Mol Psychiatry 6: 66-73, 2001.

58. Pan MH, Yang JR, Tsai ML, Sang S and HoCT: Anti-inflammatory effect of Momordica grosvenori, Swingle extract through suppressed LPS-induced upregulation of iNOS and COX-2 in murine macrophages. J Funct Foods 1: 145-152, 2009.

59. Wang WW, Smith DL and Zucker SD: Bilirubin inhibits iNOS expression and NO production in response to endotoxin in rats. Hepatology 40: 424-433, 2004.

60. Li J, Zhang $X$ and Huang H: Protective effect of linalool against lipopolysaccharide/D-galactosamine-induced liver injury in mice. Int Immunopharmacol 23: 523-529, 2014.

61. Dai C, Li B, Zhou Y, Li D, Zhang S, Li H, Xiao X and Tang S: Curcumin attenuates quinocetone induced apoptosis and inflammation via the opposite modulation of $\mathrm{Nrf} 2 / \mathrm{HO}-1$ and $\mathrm{NF}-\kappa \mathrm{B}$ pathway in human hepatocyte L02 cells. Food Chem Toxicol 95: 52-63, 2016.

62. Arranz J, Soriano A, Garcia I, García I, Concepción MT, Navarro J, Arteaga A, Filella X, Bravo P, Barrera M, et al: Effect of proinflammatory cytokines (IL-6, TNF-alpha, IL-1beta) on hemodynamic performance during orthotopic liver transplantation. Transplant Proc 35: 1884-1887, 2003.
63. Ma Q: Role of nrf2 in oxidative stress and toxicity. Annu Rev Pharmacol Toxicol 53: 401-426, 2013.

64. Kim HJ and Vaziri ND: Contribution of impaired Nrf2-Keap1 pathway to oxidative stress and inflammation in chronic renal failure. Am J Physiol Renal Physiol 298: F662-F671, 2010.

65. Fahey JW, Haristoy X, Dolan PM, Kensler TW, Scholtus I, Stephenson KK, Talalay P and Lozniewski A: Sulforaphane inhibits extracellular, intracellular, and antibiotic-resistant strains of Helicobacter pylori and prevents benzo[a]pyrene-induced stomach tumors. Proc Natl Acad Sci USA 99: 7610-7615, 2002.

66. Kensler TW, Wakabayashi N and Biswal S: Cell survival responses to environmental stresses via the Keap1-Nrf2-ARE pathway. Annu Rev Pharmacol Toxicol 47: 89-116, 2007.

67. Covas G, Marinho HS, Cyrne L and Antunes F: Activation of $\mathrm{Nrf} 2$ by $\mathrm{H}_{2} \mathrm{O}_{2}$ : De novo synthesis versus nuclear translocation. Methods Enzymol 528: 157-171, 2013.

68. Ma Z, Li C, Qiao Y, Lu C, Li J, Song W, Sun J, Zhai X, Niu J, Ren Q and Wen A: Safflower yellow B suppresses HepG2 cell injury induced by oxidative stress through the AKT/Nrf2 pathway. Int J Mol Med 37: 603-612, 2016.

69. Chang Y, Li S, Guo W, Yang Y, Zhang W, Zhang Q, He Y, Yi X, Cui T, An Y, et al: Simvastatin protects human melanocytes from $\mathrm{H}_{2} \mathrm{O}_{2}$-induced oxidative stress by activating $\mathrm{Nrf} 2$. J Invest Dermatol 137: 1286-1296, 2017.

70. Jian Z, Li K, Song P, Zhu G, Zhu L, Cui T, Liu B, Tang L, Wang X, Wang G, et al: Impaired activation of the Nrf2-ARE signaling pathway undermines $\mathrm{H} 2 \mathrm{O} 2$-induced oxidative stress response: A possible mechanism for melanocyte degeneration in vitiligo. J Invest Dermatol 134: 2221-2230, 2014.

71. Mao J, Li Z, Lin R, Zhu X, Lin J, Peng J and Chen L: Preconditioning with Gua Lou Gui Zhi decoction enhances $\mathrm{H}_{2} \mathrm{O}_{2}$-induced Nrf2/HO-1 activation in PC12 cells. Exp Ther Med 10: 877-884, 2015.

72. Lee IT, Luo SF, Lee CW, Wang SW, Lin CC, Chang CC, Chen YL, Chau LY and Yang CM: Overexpression of HO-1 protects against TNF-alpha-mediated airway inflammation by down-regulation of TNFR1-dependent oxidative stress. Am J Pathol 175: 519-532, 2009.

(i) $(-)$ This work is licensed under a Creative Commons Attribution-NonCommercial-NoDerivatives 4.0 International (CC BY-NC-ND 4.0) License. 